\title{
On the origins of the demographic transition: rethinking the European marriage pattern
}

\author{
Faustine Perrin ${ }^{1,2}$ (D) \\ Received: 10 May 2021 / Accepted: 25 July 2021 / Published online: 17 September 2021 \\ (c) The Author(s) 2021
}

\begin{abstract}
Why did France experience the demographic transition first? This question remains one of the greatest puzzles of economics, demography, and economic history. The French pattern is hard to reconcile with elucidations of the process as found in other countries. The present analysis goes back to the roots of the process and offers novel ways of explaining why people started to control their fertility in France and how they did so. In this paper, I track the evolution of marriage patterns to a point before the premises of the demographic transition. I identify two distinct phases. Next, I rely on exploratory methods to classify French counties based on their discriminatory features. Five profiles emerge. I discuss these profiles through the lens of the French Revolution, one of the greatest events that ever occurred in French history, which irretrievably altered its society. In particular, the results show that the fertility transition was not as linear, but more complex than previous research had argued. They show the importance of accounting for cultural factors and for individuals' predispositions to adapt more or less quickly to societal changes. Yet cultural factors are not all. They can help to explain the timing of the transition and the choice of methods used to control fertility, but modernity and gender equality are also needed to describe the mechanisms in play behind the process.
\end{abstract}

Keywords Demographic transition · European marriage pattern · French revolution · Gender equality $\cdot$ Women empowerment

JEL Classifications $\mathrm{J} 12 \cdot \mathrm{J} 13 \cdot \mathrm{J} 16 \cdot \mathrm{N} 33 \cdot \mathrm{O} 15 \cdot \mathrm{O} 18 \cdot \mathrm{Z} 12$

Faustine Perrin

faustine.perrin@ekh.lu.se

1 Department of Economic History, Center for Economic Demography, Lund University, Lund, Sweden

2 BETA, University of Strasbourg, Strasbourg, France 


\section{Introduction}

At the end of the eighteenth century, the French population was approaching 28 million. This population had risen due to a combination of an increasing birthrate, fewer epidemics, improved living standards, and progress in food production (Moheau 1778). France was by then the most important (and powerful) European country simply by virtue of its population. Yet a century later France experienced a major and unprecedented decline in the growth of its population, dropping to 5th position among the countries of Europe. Why did France experience the demographic transition first, and in particular, why did it do so a century before any other European country? This question is still one of the greatest puzzles of economics, demography, and economic history. The demographic transition is recognized as playing a key role in France's economic development. But the mechanisms in play and the origin of the process remain mysterious. The debate is active and divides scientists between those who favor socio-economic explanations and those who prefer cultural and diffusionist explanations (de la Croix and Perrin 2018).

France presents marked divergences from the standard model of demographic transition originally developed by Landry (1934) and Notestein (1945). The theory developed by Notestein (1945) relies on the assumption that the transition from a high birth-rate and mortality to low fertility and low mortality is an outcome of economic development and the appearance of a new system resulting from the process of industrialization and urbanization. The modernization of a society through economic development is argued to be a condition for demographic changes.

France stands as a notable exception to the classic theory of demographic transition. Two main facts isolate France from classic explanations of the demographic transition. First, the decline in mortality and fertility occurred concurrently. Second, the process started as early as the end of the eighteenth century in a society that was predominantly rural, e.g., well before the industrialization and urbanization of the country (Fig. 1).

The French-English comparison reveals a puzzling paradox. While the industrial revolution started in England at the end of the eighteenth century and the fertility transition a century later, France experienced its demographic revolution from the end of the eighteenth century and its industrialization only from the second half of the nineteenth century. The long-run trends in French population are difficult to reconcile with what is known of France's economy (Weir 1984). Why were demographic developments so late in England and so early in France, while economic developments were so early in England and comparatively late in France?

These opposite patterns question the mechanisms and predictions of the theoretical literature analyzing the long-run development process, and in particular the transition from stagnation to sustained growth (Galor and Weil 2000; Galor and Moav 2002; Voigtländer and Voth 2006; etc.). The unified growth theory explains with great pertinence the stages of development as captured by empirical 


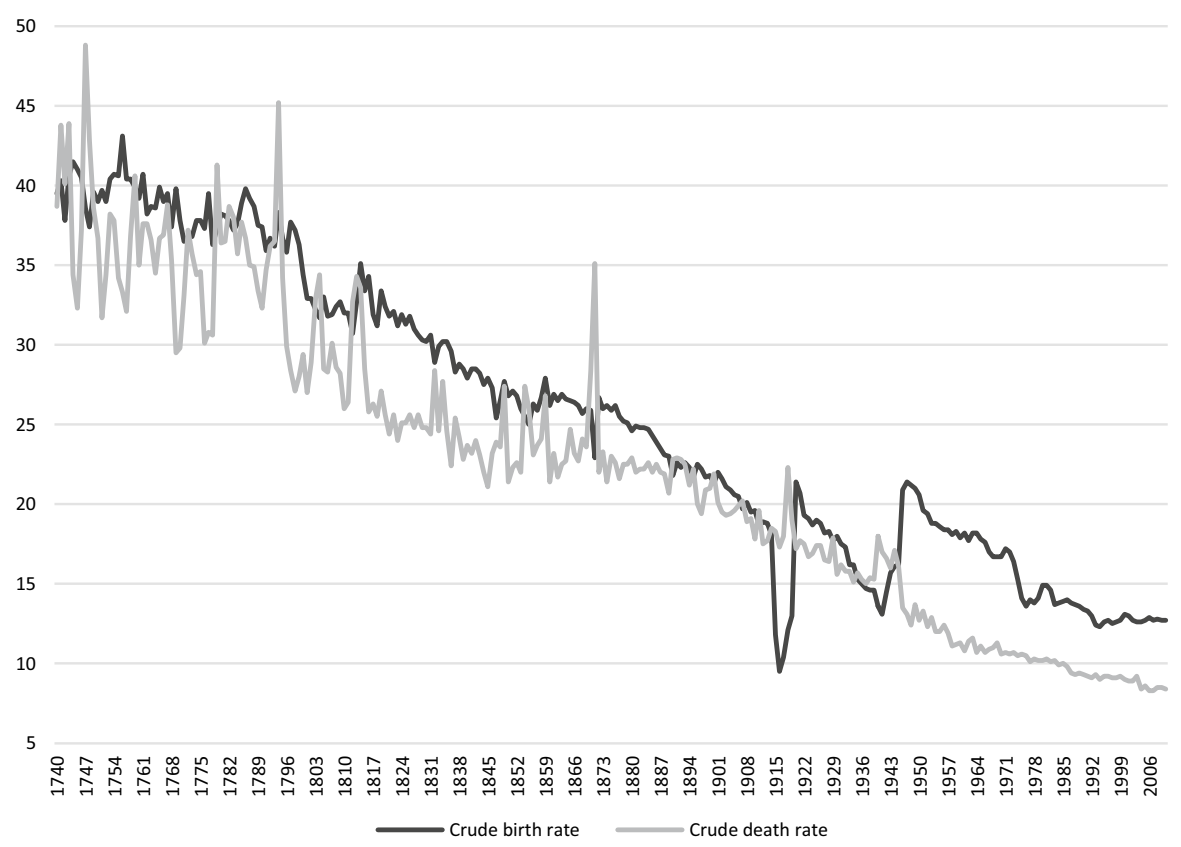

Fig. 1 Demographic Transition, France 1740-2010. Sources: Data from Chesnais (1992)—INSEE

regularities for most countries (i.e., industrialization preceding the fertility transition). But these mechanisms are inconsistent in explaining the timing of the French development process. The literature shows consistent economic explanations of the decline in fertility, in the French case as elsewhere, ${ }^{1}$ but the elements needed to reconcile the theory with the observed patterns are still missing.

In order to understand why fertility declined, we need to understand how it did so. The aim of this paper is to explain why the demographic transition evolved from its originating conditions. To answer this question, I first investigate the evolution of the marriage pattern in France from before the origins of the demographic transition. Before the development of modern methods of contraception, access to marriage was an important tool used by societies to regulate their population growth (Malthus 1798; Hajnal 1965). Next, I rely on exploratory methods to identify the specificities of French counties and to determine what set of characteristics can explain the early spread of fertility controls in certain counties and their late percolation to others. In the last part of the paper, I discuss my results in light of some of the greatest events that affected French communities and open the discussion to suggest some future directions for theoretical and empirical research.

My paper contributes to several strands of research. First, it brings new knowledge to the research on the European Marriage Pattern (EMP) and its dynamics

\footnotetext{
${ }^{1}$ See for instance Diebolt et al. (2017), de la Croix and Perrin (2018), Bignon and Garcia-Penalosa (2016) for investigations of the relationship between education and fertility.
} 
over time. On this basis, my contribution takes part to the discussion initiated by De Moor and van Zanden (2010) and questioned by Dennison and Ogilvie (2014) about the role played by the marriage pattern to explain economic development. I primarily argue that greater female agency can be reflected by a 'progressive' marriage pattern characterized by early marriages and low celibacy. I go on to argue that cultural beliefs and the stickiness of traditional norms matter in considering the question of individuals' control of their fertility. Individuals living in a progressive environment were less constrained by culture and norms with regard to marriage. In these areas, female agency could be directly reflected within marriage. I ultimately argue that areas characterized by greater female agency display higher economic development (higher GDP, lower fertility) in line with Diebolt and Perrin (2013, 2019), van Zanden and the Utrecht group, and Foreman-Peck (2011), but I show that greater female agency does not necessarily require a late marriage and a high degree of celibacy, explaining why Dennison and Ogilvie (2014) find no support for the view that the EMP improved economic performance.

An underlying contribution of the paper is to show that indicators of marital fertility should be used with caution when the fertility of a population is in question. In places where the weight of tradition is high, indicators of marital fertility may trigger misleading appreciations of fertility levels by hiding a substantial part of the story.

The paper is organized as follows. The accent is put first on the literature related to the European Marriage Pattern (Sect. 2). Second, attention moves to the changing pattern of demographic behavior in France (Sect. 3). Third, I use exploratory methods to investigate the specific characteristics of French counties in the mid-nineteenth century (Sect. 4). Lastly, I discuss my findings in light of the crucial events in France during the eighteenth century (Sect. 5).

\section{The European marriage pattern in question-related literature}

According to the adaptation hypothesis (Bonneuil 1997), individuals may resort to fertility control in reaction to changes in economic and social circumstances. But to understand why the fertility transition happened so much earlier in France than in any other country, we first need to understand how people controlled their fertility. A traditional way for individuals to regulate fertility focused on decisions about marriage, either to postpone the age of marriage or to remain single. A rich part of the literature investigates marriage habits and their evolution over time, and from comparative perspectives.

\subsection{Hajnal's seminal work}

Marriage patterns evolved over the course of the demographic transition. According to Hajnal (1965), two main features emerged from the (Western) European Marriage Pattern (EMP) which characterized western society in the Early Modern Period: 
(i) a high proportion of women never married; and (ii) women's first marriage was often unusually late in life. Hajnal's model of marriage is considered a cornerstone of historical demography. The hypotheses which he developed are based on regularities in behaviors observed between the 20th and earlier centuries; they divide countries by an imaginary line drawn from Saint-Petersburg to Trieste. Hajnal thus distinguished the EMP from the Eastern-Mediterranean European Marriage Pattern that was characterized by few women remaining single, an early age at marriage, and high fertility.

Hajnal's patterns of nuptiality are linked with two strands of the literature: Malthus's preventive checks and Laslett's and Le Play's family structures. Hajnal's theory is developed on the assumption of land scarcity and low living standards. According to Malthus (1798), two types of check can keep a population in balance with its resources: the 'positive checks' leading to premature deaths and the 'preventive checks' linked to moral restraints which induce people to postpone marriage until they are older. The low nuptiality observed in pre-industrial Western Europe would then be the consequences of couples' need to be economically self-dependent before setting up an independent household. For Wrigley and Schofield (1981) or Dupâquier (1997), marriage is the essential component of a complex system of relations between the economy, society, and demography. Marriage is the variable of adjustment through which couples have the means of taking action to control the number of births. This system can affect fertility along two channels: excluding part of the population from marriage, and consequently from procreation (definitive celibacy), and reducing women's reproductive period by increasing the age at marriage.

Hajnal developed his reflections on the links between marriage patterns and household formation systems in a second article published in Hajnal (1982). For him, the prevalence of nuclear families where parents had married late and definitive celibacy in Northwestern Europe allowed Malthusian preventive checks to operate, whereas complex household structures and early marriage outside of Northwest Europe prevented the development of such a pattern.

\subsection{Marriage pattern and economic development-the debate}

Recent writers have suggested the existence of a relationship between the Western EMP and economic development, highlighting various mechanisms. Among them, De Moor and van Zanden (2010) argue that the EMP emerged from a set of factors (the promotion of marriage based on consensus, developing labor markets, establishment of institutions concerning property transfers) that encouraged the development of wage labor for women and contributed to increased investment in formal schooling and limited population growth, which underlay rapid economic development. In an extension of this seminal work, van Zanden et al. (2019) explain how the development toward today's European marriage pattern-reflecting female empowerment-was one of the main causes of the gradual move away from a Malthusian state toward an economy able to generate long-term economic growth. Similarly, Foreman-Peck (2011) develops a model in which the EMP influences economic development by promoting higher investment in human capital and limiting 
population growth through greater female agency. Voigtländer and Voth (2013) argue that the population shock caused by the Black Death and women's comparative advantage in the pastoral sector offered greater opportunities for women to work in the labor market that resulted in later marriage. For the authors, the EMP-used by the European population to control their fertility-enabled them to enjoy living standards above subsistence level long before the industrial revolution.

Despite the difficulty of accessing detailed and extensive information, a few attempt have been made to empirically investigate the relationship between the EMP and economic developments. Among them, Dennison and Ogilvie (2014) have conducted a meta-analysis of the demographic characteristics of thirty European societies from both sides of Hajnal's line. They find that certain regions characterized by a late industrial development married later than the UK, which industrialized first. Dennison and Ogilvie conclude from their analysis that no evidence supports the view that the EMP improved economic performance by empowering women, increasing human capital investment, adjusting population to economic trends, or sustaining beneficial cultural norms. For Dennison and Ogilvie (2014), the European economic success was not caused by the EMP at all and its origins must be sought in other factors.

Carmichael et al. (2016) point out the absence of a dynamic perspective in the analysis conducted by Dennison and Ogilvie (2014). The authors also recall the importance of accounting for the economic circumstances and underlying institutions for understanding the dynamics of demographic and marriage patterns. This understanding shows us why, in successful economies based on marriage consensus, we can expect that the age at marriage will be lower than it is in stagnating economies.

\subsection{Challenges to Hajnal's model}

Some of the conceptual issues emphasized by the debate opened by Dennison and Ogilvie (2014) raise interesting questions about Hajnal's model itself and echo an array of demographic writing that challenges it on several fronts.

There are (empirical) reasons to question the economic logic implied by Hajnal's model of marriage behavior. Beyond the model that he describes, a great variety of situations can be found (Livi Bacci 1999). ${ }^{2}$ Low nuptiality is found in groups to which the Malthusian constraint does not apply (e.g., marriage was not earlier in cities than in rural areas, nor earlier in bourgeois families) and high nuptiality is found in regions where the Malthusian constraint should apply. Le Bras (1996) summarizes a number of critics who inveigh addressed against the narrow view of demographic models in which a single variable of adjustment - the age at marriage-enables the population to adjust itself to the available resources. Such approaches tend to ignore the dynamics of the economic system and the possibility of technological and economic progress, to say nothing of the role played by traditions, norms, and cultural specificities. The explanation of the mechanisms is based on homogeneity of behavior. It is assumed that, everything else being equal, individuals will behave

\footnotetext{
2 See Lundh (1997) for a discussion of the marriage pattern in Sweden over the 1650-1990 period.
} 
in the same way as each other. These models do not take into account individual characteristics, social conditions, or types of activity (Le Bras 1996). Studying the case of pre-industrial England, de la Croix et al. (2019) find that once celibacy and childlessness were taken into account the middle classes were the most successful socio-economic group in terms of reproduction. Their analysis shows that demographic behaviors varied substantially by class.

Additionally, these types of model rely on the assumption of nuclear households (Bideau 1983), but these were not common to all Western European regions (Todd 1983, 2011). Braudel (1990) notes the diversity of territories and societies within France and the fact that, before the Revolution, each portion of the territory tended to live closed in upon itself. For Braudel, the population could rely on demographic adjustments to maintain the economic-demographic equilibrium of a territory, delaying marriage to control births, but could also find economic solutions. The development of handcraft activities and rural industries is an example.

Levine (1977) argues that the development of proto-industrialization triggered early marriage and population growth. For Flinn (1981), a key feature of economic development in many countries-especially during the late eighteenth century-was the expansion of domestic industry that triggered a growing proportion of the population to marry earlier and produce more children than the average. Proto-industrialization enabled individuals to gain in independence and to constitute their household independently of the ownership of land, thanks to the increasing availability of paid employments (Birdsall 1983; Galloway et al. 1998) that contributed to weaker Malthusian preventive checks (Mendels 1984). Yet various trends came to gainsay the relationship between proto-industrialization and age at marriage (see Gutmann and Lebotte 1984). Vandenbroeke (1987) and Devos (1999), studying the case of Flanders, both observe a greater control of marriage in parallel to the development of proto-industrialization. No clear and definitive trend could be established in empirical studies of the relationship between proto-industrialization and age at marriage. The diversity of observed patterns questions the consistency of the relationship linking EMP and economic circumstances.

Demographic patterns are argued to be associated with economic circumstances. ${ }^{3}$ When the economic situation is bad, households rely on late age at marriage to adjust their fertility downwards. ${ }^{4}$ When the economic situation is good, people can

\footnotetext{
3 Additional factors can affect demographic behaviors. Among them is the influence of epidemics on demographic evolutions. Bourdelais (1997) reviews existing knowledge and literature on the impact of epidemics on human societies. Biological phenomenon affected human history (see Omran 1971). It notably did so by influencing mortality rates and fertility behaviors (Le Roy Ladurie 1967). In parallel to the mitigation of epidemics that happened in the nineteenth century, modernization greatly contributed to the improvement of hygiene and sanitation conditions, more particularly in urban areas. As an example, the prefect of Paris, Haussmann, launched in 1852 a planning project to modernize the capital. The creation and development of the sewage system greatly contributed to the improvement of hygiene conditions in the city and contributed to the decline of mortality (Kesztenbaum and Rosenthal 2017).

${ }^{4}$ Le Bris and Tallec (2021) provide empirical support for the existence of such relationship. Based on individual-level data for the village of Montesquieu-Volvestre (located in Southwestern France) over the 1660-1789 period, the authors show that female age at marriage adjusts to economic conditions. As a resulting effect, households have fewer children, the spousal age gap declines, and women have greater agency within the couple.
} 
marry early, resulting in higher fertility and population growth. However, the coexistence of a variety of situations, whose explanations/mechanisms seem to contradict each other, should encourage us to search for additional or complementary factors that could explain these specificities.

\section{France and the marriage pattern paradox}

The marriage pattern is connected to economic development in many ways-but undoubtedly in more complex ways than often argued so far. The mystery of the French demographic transition widens when we take a closer look at the French marriage pattern. It is not as linear and simple as often presented (as symbolized by the Trieste-Saint-Petersburg line dividing Western from Eastern Europe). Its geography is not so simple; neither is its evolution over time.

\subsection{Celibacy}

Hajnal (1983) concludes his article by the statement, '[at] the end of the nineteenth century the European pattern of late marriage certainly extended beyond the boundaries of Northwestern Europe.' Alter (1991) complements Hajnal, arguing that 'the Western European Marriage Pattern continued into the nineteenth and twentieth centuries after all pretenses of Malthusian limitations had been lifted.' What we observe in nineteenth century France differs from the empirical regularities observed at the time in other European countries and questions the major intuitions behind Hajnal's model. In France, the marriage pattern evolved significantly over time. The long-run evolution of the key variables of the marriage pattern reveals surprising trends.

Figure 2 presents the evolution of the female (red line) and male (blue line) definitive celibacy rates over the $1670-1855$ periods. An individual is considered as definitively single when s/he reaches the age of 50 without ever having married. Two key periods can be identified from Fig. 2. The share of definitive celibacy continuously increased from the mid-seventeenth century to the French Revolution (highlighted in gray) for women, and until the 1830 s for men. ${ }^{5}$ For women's celibacy, the pace of the increase was faster. The rate increased from about 50 (definitive) single women per one thousand individuals in the $1670 \mathrm{~s}$ to 140 (definitive) single women per one thousand individuals at the turn of the 1790s. Within 120 years, the share of single women had increased almost threefold and the share of single men had increased by 1.3 . The share above of individuals never marrying is normally used to capture high definitive celibacy. The trends observed during the seventeenth and eighteenth centuries confirm Hajnal's observation of high celibacy in the Western European population. What becomes puzzling is what happens next.

Although definitive celibacy remained relatively high at the beginning of the nineteenth century, the trends experienced complete reversal. The period of the French Revolution marks the turning point for women's definitive celibacy. One has

\footnotetext{
5 See Derouet (1996), Brée and de la Croix (2019) for studies about childlessness in the pre-industrial period in Franche-Comté and Rouen, respectively.
} 


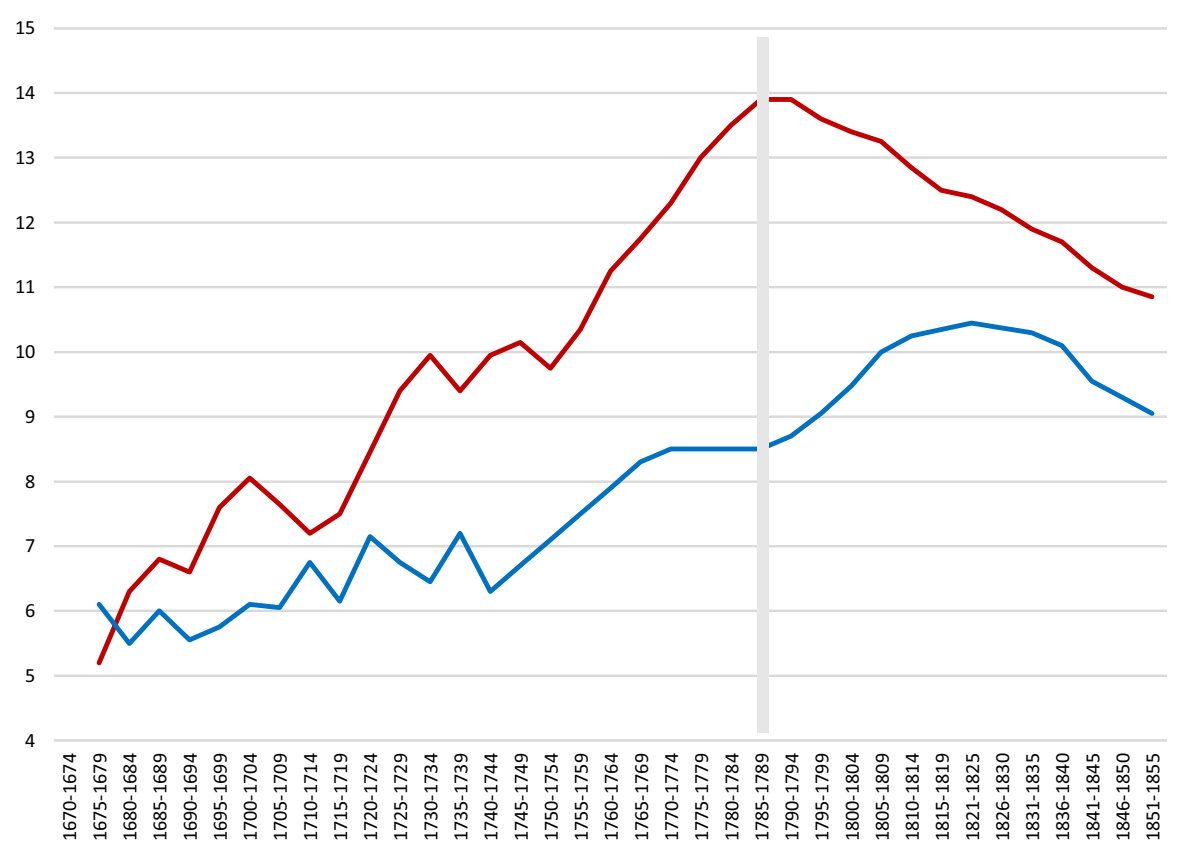

Fig. 2 Share of Single Women and Men (\%). Sources: Data from Henry and Houdaille (1978)

to wait until the 1830 s to observe a similar reversal for men's definitive celibacy. During the nineteenth century, as it went through its process of demographic transition, France was a country with an active nuptiality. The increase in celibacy has traditionally been argued to be a feature of modernity contributing to increased autonomy for individuals, including females. The decline in female celibacy observed in parallel to the fertility transition comes as a great surprise. And this unexpected evolution does not come alone; it accompanies a decline in the age at marriage.

\subsection{Age at first marriage}

The second key characteristic of the European marriage pattern is the rising age at marriage. Figure 3 presents the evolution of the median age at marriage by gender between 1740 and 1950. The female (red line) and male (blue line) age at marriage follow a fairly similar evolution given that men always marry later in life than women do.

The mean age of males upon marriage reached 29 at the end of the Ancien Régime, while that of women reached 27. Relatively late during the second half of the eighteenth century, the average age at marriage dropped a few years until the turn of the nineteenth century - at a faster pace and to a greater extent for women (after a brief period of stability around age 24 over the period 1880-1900). The age at first marriage reached its lowest point in the 1950s with a median age of 22.6 for women and 24.7 for men. Men and women were marrying about 4.5 years younger on average in the 1950s than in the 1790s. 


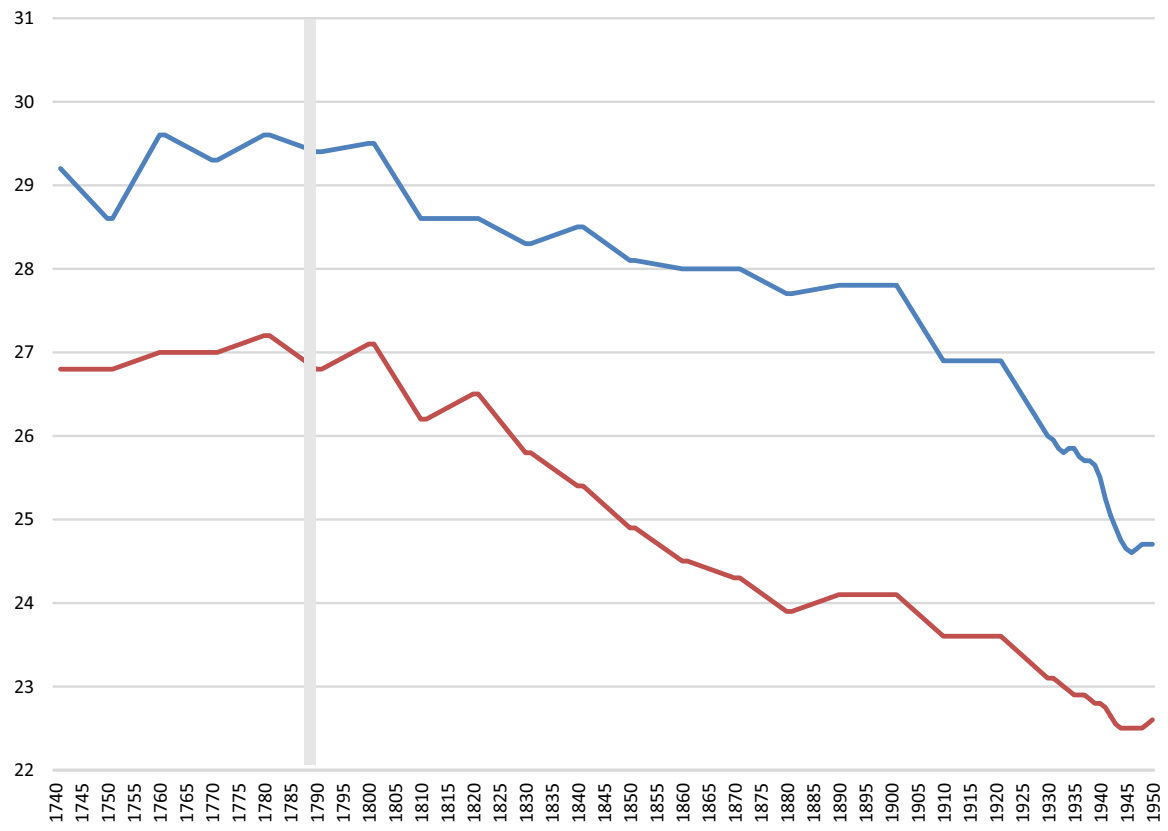

Fig. 3 Median Age at Marriage by Gender. Sources: Data from Henry and Houdaille (1979)—INED

Hence, we distinguish two main periods in the evolution of age at marriage over the studied period. Between 1740 and the French Revolution, we note a slight increase in the median age at marriage for both genders. From the French Revolution onwards, we observe an important drop in the female and male median age at marriage- only temporarily interrupted by a slight increase during the July Monarchy (Henry and Houdaille 1979) - in which the rate of increase for women was faster. Like the rate of definitive celibacy, the mean age at marriage surprisingly declined both for men and women in parallel to the fertility transition. The empirical observations of the French marriage pattern over the long run seem to contradict the argument that the EMP persisted into the nineteenth and twentieth centuries and was diffused from Northwestern Europe to other regions. ${ }^{6}$

\subsection{Illegitimate births}

An additional underlying characteristic of the EMP is the low rate of illegitimate births. ${ }^{7}$ Figure 4 shows the evolution of the share of illegitimate births between 1740

\footnotetext{
${ }^{6}$ It was only from the 1960 s that men and women started to marry later in life than the previous generations had, and only in the 1980s that they reached the levels displayed in the 1790s (see Perrin 2013; Diebolt and Perrin 2017).

7 Reducing the pressure on fertility is expected to produce a lower illegitimate birth-rate, although postponing marriage might in parallel increase the risk of illegitimate births.
} 




Fig. 4 Frequency of Illegitimate Births. Sources: Data from Segalen and Fine (1988)

and 1913. Before the French Revolution, the number of illegitimate births was relatively low. Over the 1780-1789 period, only 2.6 per one hundred births were illegitimate-even fewer in the decades preceding the Revolution (Fig. 4).

The increase in the frequency of illegitimate births began before the fateful period of the Revolution. Then the frequency of illegitimate births accelerated from the 1800 s until the 1840s. In the following decades, the share of out-of-wedlock births oscillated around 7.4 in every hundred births. A second period of increase occurred in the 1870 s before stabilizing at around 8.7 illegitimate births in every hundred at the turn of the twentieth century. The frequency of illegitimate births increased sharply over our studied period. Across the nineteenth century, births out of wedlock multiplied by $200 \%$-rising from $3 \%$ to almost $9 \%$. The high share of illegitimate births reflects the weakening of moral and social controls on fertility behaviors.

While the pattern of late and non-universal marriage, coupled with low levels of out-of-wedlock childbirth is argued to have triggered a massive reduction in fertility, France presents a totally different and counter-intuitive picture of marriage patterns and fertility control. Important transformations affected the marriage pattern in France over the course of the demographic transition. Two crucial periods emerge from the evolution of marriage practices over the studied period. The first period-before the French Revolution-was characterized by the classical features of the European Marriage Pattern, as described by Hajnal (1965). The data indicate the existence of a very large number of individuals who never married. In addition, the age at marriage was late for both genders and the frequency of illegitimate fertility was low. The second period, starting after the Revolution (in the 1790s), presents 
a reversal in the trends observed so far. The share of definitive celibacy fell sharply (to a greater extent for women), the median age at marriage set off on an impressive downward path, and the share of illegitimate births rose at a sustained pace.

\subsection{Missing pieces of the puzzle}

The characteristics of the marriage pattern during the first period easily explain why French women had fewer children. More women remaining single all their lives or marrying older reduces the period of fertility and hence the number of births. But the fertility transition in France started jointly with the reversal of these trends, i.e., jointly with the fall of definitive celibacy, the decline of the age at marriage, and the rise of illegitimate births. Following the reasoning used for the first period, one would expect fertility to rise when such conditions prevailed. And yet the country plunged into an unprecedented fertility transition.

Something clearly happened in France that changed attitudes toward procreation (Vovelle 1977). Those who seek to explain fertility transitions offer two main strategies of fertility limitation. A traditional way to regulate fertility consists in controlling the incidence of marriage: the Malthusian way. A more modern way of controlling fertility consists in playing with the level of fertility within marriage: birth control. The decline of fertility in parallel to an active nuptiality suggests the emergence of a new way of controlling fertility. ${ }^{8}$ A transition occurred in France from controlling marriage to controlling fertility within marriage. The transformation of the marriage pattern in France reflects a deep change: that of French society as a whole.

The marriage pattern as described by Hajnal, and works in line with his, seem to omit an important part of the story, notably the fact that the population could voluntarily control births within marriage. The drop in the French birth-rate did not result from the development of celibacy and the increased age at marriage (as it had done in the past). It was due to the limitation of the number of births to married parents. The French pattern suggests the dismantling of the EMP of collective abstinence in favor of birth control. The widespread use of contraception technics-such as withdrawal or periodic abstinence (Salles 2019) — can be explained by the evolution in attitudes and changed ways of thinking and not by a sudden and generalized transgression of prohibition (Burguière 1972). ${ }^{9}$ It could therefore explain why it happened first in France, which was not so distinctive from an economic standpoint but stood out by virtue of its intellectual movements and advanced state of secularization.

\footnotetext{
8 As Bengtsson and Dribe (2006) show in the context of Southern Sweden, before the fertility transition people deliberately controlled the time of childbirth as a response to short-term economic stress.

9 It is worth mentioning the existence of the 'faiseuses d'anges' (angel makers). The 'faiseuses d'anges' were acting to intentionally terminate other women's unwanted pregnancies. Abortion practices were clandestine, but without reliable contraception methods to control births, such practices were widespread and even tolerated at the time in certain departments (Le Naour and Valenti 2003). Le Mée (1986) provides a rich discussion about abortion practices in France in the nineteenth century through of the judicial case of 'the abortionists of Paris.'
} 


\section{Analysis-typology}

The mystery surrounding the French demographic transition and the reversal of the marriage pattern can be dispelled by regional and spatial investigations. Nineteenthcentury France is known for being highly heterogeneous. It is therefore an ideal candidate for exploratory methods. The exploratory methods used in this section aimed to reveal the existence of clusters. I sequentially used two multivariate statistical techniques. First, I ran the principal component analysis needed to reduce the number of variables. Second, I relied on a hierarchical cluster analysis to identify clusters and establish a typology of French counties based on their demographic and socio-economic characteristics in the 1850 s.

\subsection{Principal component analysis}

Principal component analysis (PCA) enables us to condense information from interdependent variables to a smaller set of factors (Jolliffe 2002). Before running PCA, the dataset is checked for appropriateness. I used the Kaiser-Maier-Olkin measure (KMO) of sampling adequacy to test whether the variables were largely independent or correlated very closely. The numbers were all above 0.5 , which justified the use of principal component analysis.

The purpose of this exploratory method was to synthetize the information contained in a dataset by reducing the number of dimensions of the dataset, in order to identify and uncover latent patterns. PCA uses orthogonal transformations to convert a set of possibly correlated variables into a set of linearly uncorrelated variables (called principal components). ${ }^{10}$ To construct a typology of fertility and marriage patterns, I reviewed the major influences on these things, selecting 25 quantitative variables. The variables capture a set of socio-economic, demographic, and cultural characteristics in the PCA. Table 1 presents the descriptive statistics of the variables used in the analysis. Most of the variables come from the Statistique Générale de la France. These variables are available for 85 counties (corresponding to NUTS-level 3 ) and concern the $1850 \mathrm{~s}$.

A crude birth rate of 30 children per one thousand individuals is a level from which we can distinguish counties using birth control from those that do not. Above this level, it is likely that only a very small segment of the population uses fertility control. A crude birth rate below 20 children per one thousand individuals, however, suggests that a large segment of the population practices birth control (Chesnais 1992). Hence counties experiencing a fertility transition should exhibit intermediate crude birth rates ranging between 30 and 20 per one thousand individuals. As shown in Table 1, the average crude birth rate in mid-nineteenth century France was 26, ranging from a minimum of 17.7 (in Calvados) to a maximum of 33.5 (in Cher). Although the fertility transition had affected France about half a century before, fertility behaviors remained significantly heterogeneous across counties.

\footnotetext{
10 See Henning et al. (2011), Chilosi et al. (2013), Perrin and Benaim (2019) for recent applications in a historical context.
} 
Table 1 Descriptive statistics—French counties, 1850s. Sources: Data from Statistique Générale de la France (see Appendix A for a description of the variables)

\begin{tabular}{|c|c|c|c|c|c|}
\hline Variable & Observations & Mean & $\begin{array}{l}\text { Standard } \\
\text { Deviation }\end{array}$ & Minimum & Maximum \\
\hline Marital fertility & 85 & 3.21 & 0.58 & 2.07 & 4.77 \\
\hline Crude birth rate & 85 & 25.94 & 3.50 & 17.77 & 33.54 \\
\hline Share married women & 85 & 53.53 & 5.75 & 43.06 & 64.15 \\
\hline Male age at marriage & 85 & 30.51 & 1.49 & 27.55 & 33.97 \\
\hline Female age at marriage & 85 & 26.09 & 1.39 & 23.16 & 29.40 \\
\hline Early marriage & 85 & 17.18 & 6.38 & 1.91 & 29.68 \\
\hline Definitive celibacy & 85 & 12.11 & 4.25 & 5.31 & 26.31 \\
\hline Illegitimate birth, urban & 85 & 12.10 & 4.74 & 3.04 & 26.01 \\
\hline Illegitimate birth, rural & 85 & 3.83 & 1.88 & 1.16 & 8.45 \\
\hline Infant mortality & 85 & 29.99 & 7.83 & 16.21 & 48.34 \\
\hline Male literacy & 85 & 66.52 & 19.40 & 28.90 & 98.40 \\
\hline Female literacy & 85 & 49.87 & 23.77 & 15.90 & 95.40 \\
\hline Boys' school enrollment & 85 & 44.47 & 17.35 & 15.54 & 86.08 \\
\hline Girls' school enrollment & 85 & 29.57 & 21.08 & 0.29 & 80.96 \\
\hline Male employed agriculture & 85 & 73.72 & 17.23 & 4.62 & 113.5 \\
\hline Male employed industry & 85 & 5.77 & 8.14 & 0.15 & 63.64 \\
\hline Female employed agriculture & 85 & 61.60 & 17.92 & 3.64 & 105.4 \\
\hline Female employed industry & 85 & 3.62 & 7.04 & 0.01 & 55.15 \\
\hline Protestant & 85 & 2.28 & 5.36 & 0.00 & 31.37 \\
\hline Civil Constitution of Clergy & 85 & 55.93 & 23.70 & 5.00 & 94.00 \\
\hline Inequality in agriculture & 85 & 36.30 & 17.98 & 4.07 & 81.46 \\
\hline Agglomerated population & 85 & 22.31 & 12.98 & 8.42 & 94.98 \\
\hline Density & 85 & 102.0 & 318.4 & 21.87 & 2991 \\
\hline Gender gap index & 85 & 70.84 & 6.84 & 57.65 & 86.29 \\
\hline GDP per capita & 85 & 504.9 & 141.1 & 273 & 1105 \\
\hline
\end{tabular}

The demographic variables used in the analysis captured fertility behaviors (crude birth rates and marital fertility), marriage patterns (age at marriage, celibacy, share of married women, share of early marriages ${ }^{11}$ ), infant mortality, and out-ofwedlock births. As education variables, I used the literacy rates and the enrollment in public primary schools. Among the economic variables used in the analysis were the level of urbanization (density and agglomerated population), the occupational structure (employment in industry and in agriculture), landownership inequality measured by the share of landowners, ${ }^{12}$ and the wealth captured by the GDP per capita. With regard to the cultural variables, religious practices are captured by the

\footnotetext{
11 The share of early marriage is measured as the share of women who married below the age of 25.

12 Galor, Moav, and Vollrath (2009) suggest that the concentration of landownership adversely affected the emergence of institutions promoting human capital and therefore affected the pace and the nature of the transition from an agricultural to an industrial economy.
} 


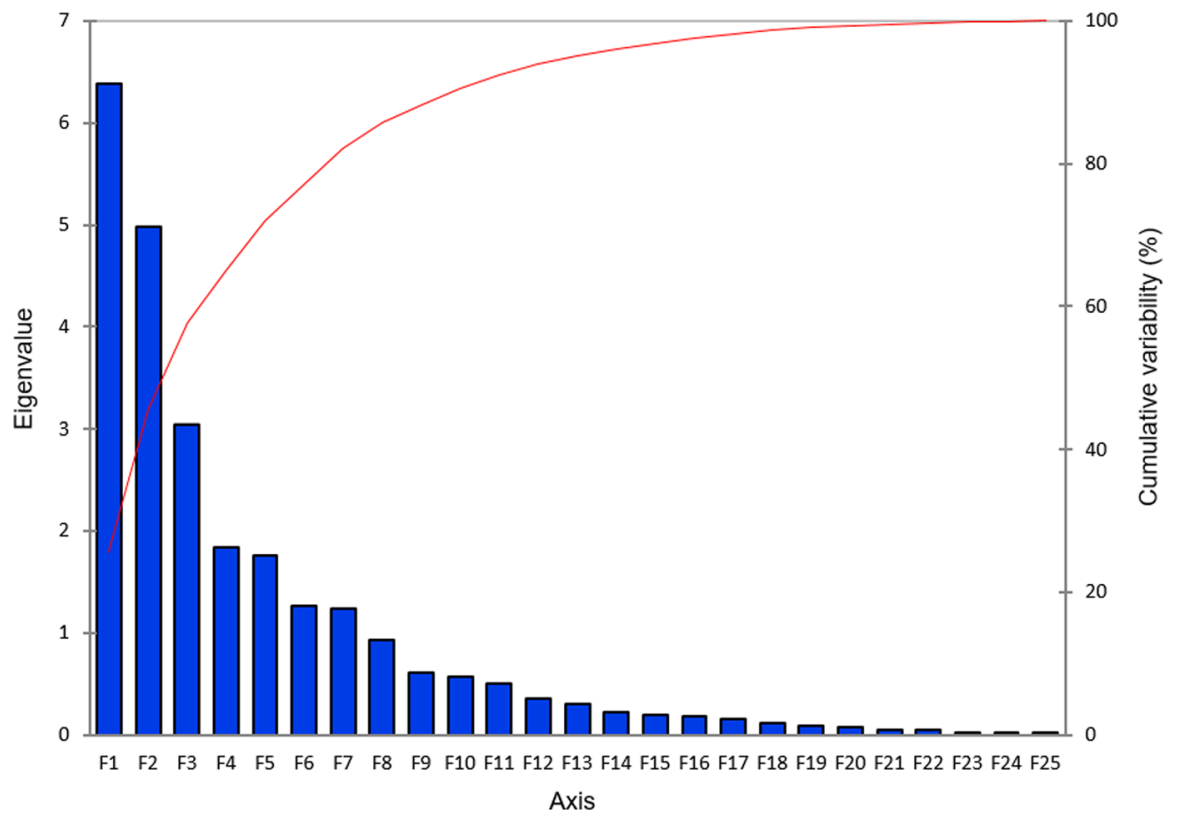

Fig. 5 Scree Plot

share of Protestants and by the share of juring priest in 1791 (Civil Constitution of the Clergy). The variables when accurate account for the gender dimension. ${ }^{13}$

Seven principal components present eigenvalues greater than 1 , as shown by the scree plot presented in Fig. 5. These 7 components explain $82 \%$ of the total variability. To avoid redundancy, I present and integrate in the remaining part of the analysis only the five major components out of the seven displaying eigenvalues greater than 1 . These 5 components explain $72 \%$ of the total variability. In order to simplify the interpretation, the principal components are identified using orthogonal rotation (varimax-Kaiser) that allow us to put a smaller number of highly correlated variables under each component. Table 2 presents the key characteristics of each component. From each column, it is possible to define the variable with which each component is most closely associated. Only correlations above 0.3 are presented. The first principal component of a set of variables is the linear index that captures the largest amount of information common to our variables (Filmer and Pritchett 2001).

The first component (PC1), which explains $25 \%$ of the variance, is positively correlated with the literacy and enrollment rates in public primary schools for both genders. PC1 represents the overall level of human capital. The second component (PC2) is almost as important as the first and explains $20 \%$ of variance. This component is related to the marriage pattern (modern/natural vs. traditional). It is closely

\footnotetext{
13 The variables are normalized to remove scale effects. Accordingly, a variable that varies from 0 to 100 does not more weight more than a variable that varies from 1 to 1000 .
} 
Table 2 Five Components of the PCA - orthogonal varimax rotation

\begin{tabular}{|c|c|c|c|c|c|}
\hline Variables & $\mathrm{PC} 1$ & $\mathrm{PC} 2$ & PC3 & $\mathrm{PC} 4$ & PC5 \\
\hline Marital fertility & & & & 0.486 & \\
\hline Crude birth rate & & & & 0.481 & \\
\hline Share married women & & 0.436 & & & \\
\hline Male age at marriage & & -0.371 & & & \\
\hline Female age at marriage & & -0.418 & & & \\
\hline Early marriage & & 0.388 & & & \\
\hline Definitive celibacy & & -0.398 & & & \\
\hline Illegitimate birth urban & & & & -0.334 & \\
\hline \multicolumn{6}{|l|}{ Illegitimate birth rural } \\
\hline Infant mortality & & & & 0.340 & \\
\hline Male literacy & 0.448 & & & & \\
\hline Female literacy & 0.424 & & & & \\
\hline Boys school enrollment & 0.471 & & & & \\
\hline Girls school enrollment & 0.434 & & & & \\
\hline Male employed agriculture & & & -0.380 & & \\
\hline Male employed industry & & & & & 0.565 \\
\hline Female employed agriculture & & & -0.346 & & \\
\hline Female employed industry & & & & & 0.545 \\
\hline Protestant & & & & 0.379 & \\
\hline Civil Constitution of Clergy & & 0.315 & & & \\
\hline Inequality in agriculture & & & & & -0.364 \\
\hline Density & & & 0.504 & & \\
\hline Agglomerated population & & & 0.488 & & \\
\hline \multicolumn{6}{|l|}{ Gender gap index } \\
\hline GDP per capita & & & 0.318 & & \\
\hline
\end{tabular}

correlated with the share of married women $(+)$, the female and male ages at marriage (-), the proportion of women who married early (below 25 years old) (-), and definitive celibacy $(+)$. Additionally, this component correlates closely with the share of juring priests (i.e., those who swore an oath of loyalty to the Civil Constitution of the Clergy (+), which captures the low weight of religious practice and traditions in the counties exhibiting a high share of juring priests (see below). The third component (PC3), which explains $12 \%$ of variance, is closely correlated with the density and agglomerated population. It represents the urban vs. rural structure of the economy. Figure 6 provides an illustration of the positioning of French counties along the factorial axes PC1 and PC2 (Fig. 6a) and PC1 and PC3 (Fig. 6b). ${ }^{14}$ The

\footnotetext{
${ }^{14}$ The length of the vector reflects the representativeness of the investigated PCA dimensions. If a variable has a short vector length on dimensions PC1 and PC2, its information is likely to be better represented on other PCA dimensions. Narrow angles depict positively linked variables (e.g., definitive celibacy and age at marriage). Right angles represent variables that are unrelated to each other. Obtuse angles depict negative relationships (employment in agriculture and agglomerated population).
} 
French counties appear in blue and the variables used in the analysis are represented by red vectors (Fig. 6).

The fourth (PC4) and fifth (PC5) components both explain $7 \%$ of the variance. PC4 is positively related to fertility and is referred to as reproductive behavior. PC5 is positively correlated with men and women working in the industrial sector. It represents the industrial sector (as opposed to the primary and tertiary sectors).

\subsection{Hierarchical cluster analysis}

PCA enabled us to extract essential information from the dataset and express latent structures within a few variables (principal components). Combining a hierarchical cluster analysis (HCA) with our PCA allowed us to group our counties in relevant clusters based on their (socio-economic, demographic, and cultural) characteristics.

HCA is a method which explores the organization of samples in groups and among groups presenting a hierarchy (Lee and Yang 2009). From a set of 85 individuals (in our case, counties), the HCA spreads the individuals into a number of heterogeneous groups within which individuals share homogeneous characteristics. The first five factors of the PCA are used for hierarchical clustering with Euclidean Distance as distance measure and Ward's computation method as agglomerative clustering. The dendogram ${ }^{15}$ resulting from this method illustrates the sequence in which the counties were partitioned into clusters (Fig. 7).

A choice of six clusters was retained. This number of clusters appeared the most appropriate and presented the most meaningful association of counties. ${ }^{16}$ The centroids of each class are presented in Table 3. Class 6, comprising one single county, is very different from the rest of the sample and appears as a clear outlier. Its density, agglomerated population, and GDP per capita are all considerably larger than any other county. The remaining five classes present a pertinent typology.

Characteristics of the clusters:

- Class 1-Counties within class 1 are characterized by endowments in human capital below the national average. These counties present the characteristics of the Eastern EMP, without any clear and direct evidence of fertility control. Fertility rates are close to the national average. The labor force is mostly agrarian.

- Class 2-Counties belonging to class 2 present a high endowment of human capital for both men/boys and women/girls. These counties present the characteristics of the Eastern EMP. Men and women marry earlier than anywhere else in France. The share of women who marry below the age of 25 is the highest. The share of married women is also the highest and the share of definitive celibacy is the lowest. Yet these counties present the lowest fertility rates reported

\footnotetext{
15 A dendogram is a diagram representing a tree. It is frequently used to illustrate the arrangement of the clusters produced by corresponding analyses. Such graphs contain vital information about the distances measured in the clustering and the pairings generated.

16 Empirically, the 'elbow' method confirms the relevance of using 6 classes. Additionally, when calculated the second order differences of the within-class variance for 1 to 15 clusters, class 6 scores the highest.
} 
(a) Biplot (axes PC1 and PC2: $45.46 \%$ )

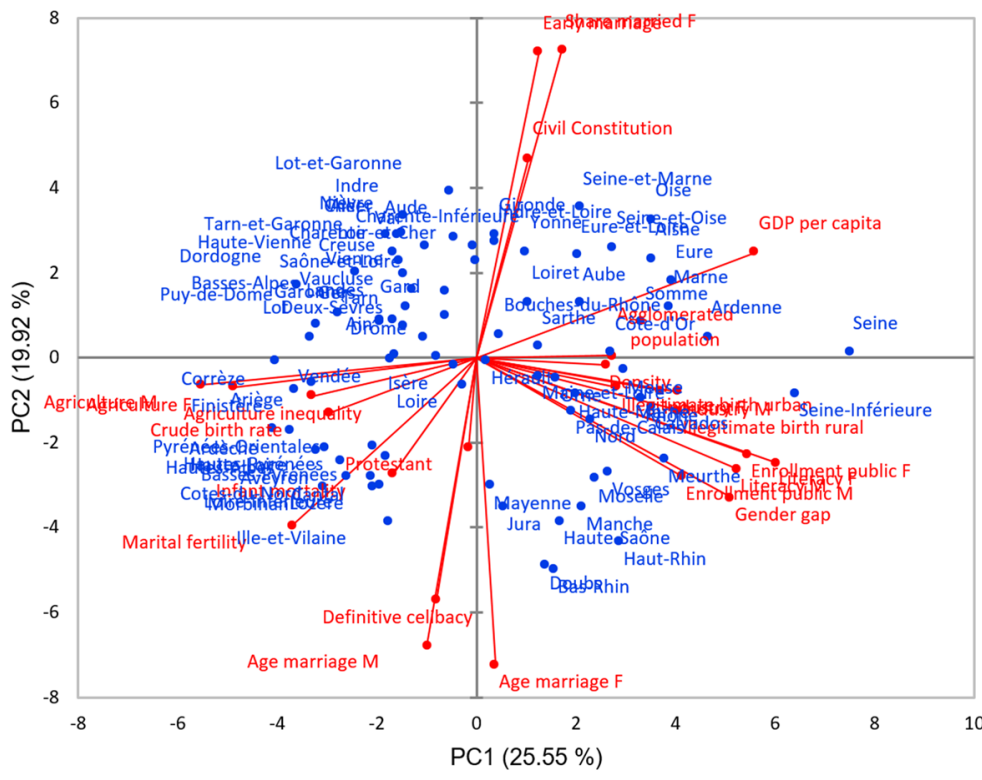

- Active variables - Active observations

(b) Biplot (axes PC1 and PC3: $37.71 \%$ )

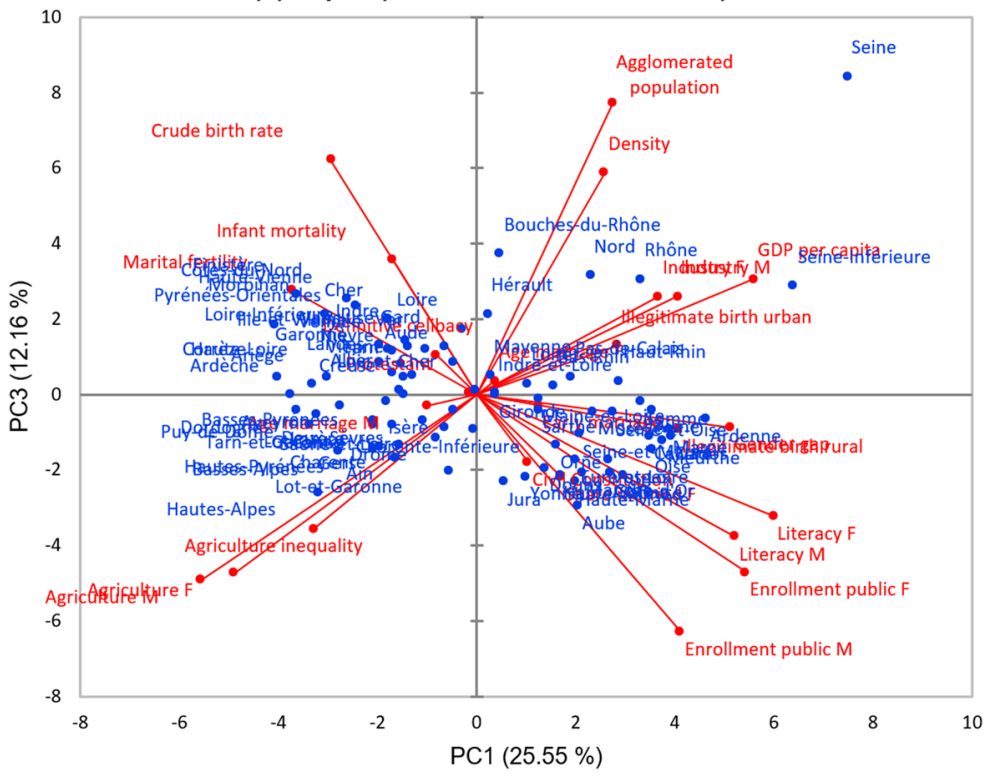

- Active variables - Active observations

Fig. 6 Biplots. Notes: Fig. 11 in appendix shows the correlation circles 
Table 3 Class centroids

\begin{tabular}{lcccccl}
\hline & PC1 & PC2 & \multicolumn{1}{c}{ PC3 } & \multicolumn{1}{c}{ PC4 } & \multicolumn{1}{c}{ PC5 } & Obs \\
\hline Class 1 & -1.401 & 1.585 & -0.088 & -0.013 & -0.096 & $N=32$ \\
Class 2 & 2.970 & 2.034 & -1.196 & 0.323 & 0.412 & $N=13$ \\
Class 3 & -2.805 & -2.155 & 0.635 & -0.448 & -0.069 & $N=15$ \\
Class 4 & 1.684 & -0.339 & 2.572 & 0.856 & 1.582 & $N=70$ \\
Class 5 & 2.021 & -2.229 & -1.105 & -0.213 & -0.242 & $N=17$ \\
Class 6 & 7.492 & 0.138 & 8.435 & 1.422 & -7.055 & $N=10$ \\
\hline
\end{tabular}

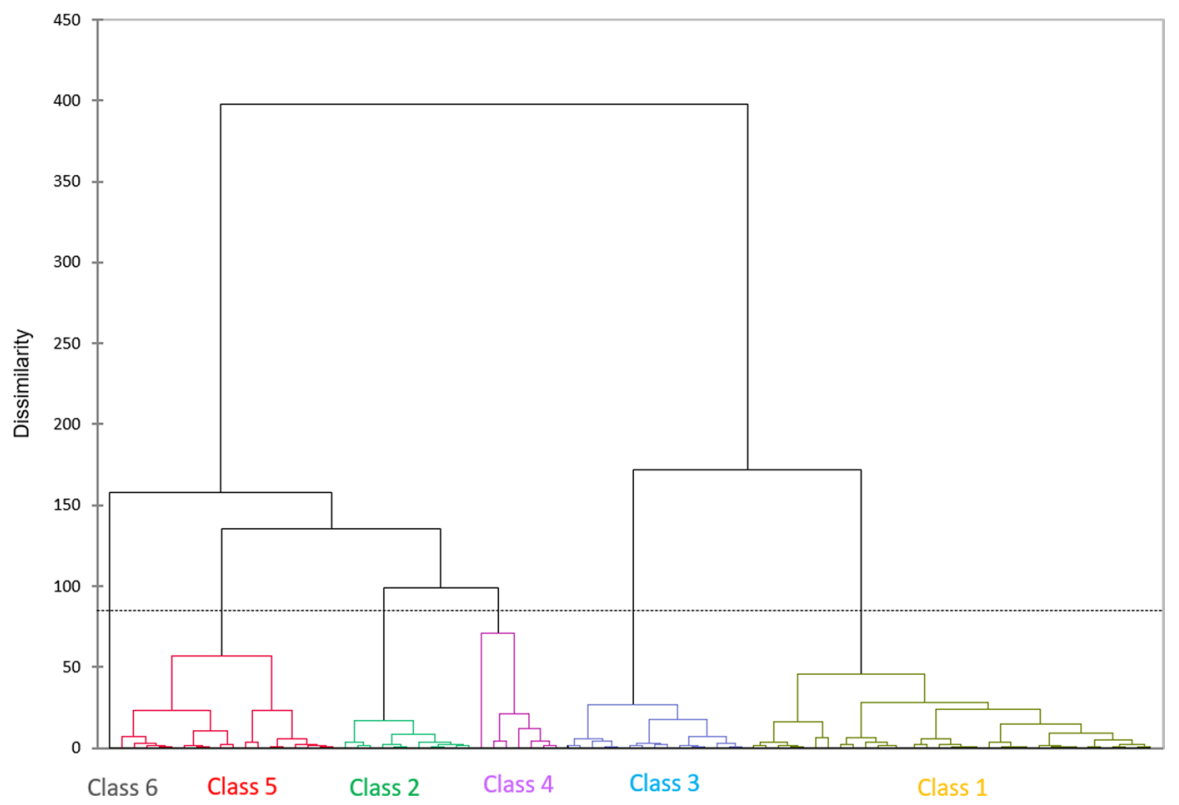

Fig. 7 Dendogram

in France. The population living in these counties is highly educated and exerts fertility control within marriage. This population is sparse and rural but benefits from a dynamic industrial sector.

- Class 3-Like those in class1, the counties belonging to class 3 present endowments in human capital below the national average. But unlike class 1 counties, these present the characteristics of the Western EMP and exhibit high fertility rates. The great majority of the population living in these counties make their living from agricultural pursuits.

- Class 4-Class 4 is the most closely marked by the industrial sector. Its population is dense and agglomerated and its fertility is above average. Endowments in human capital and marriage patterns vary substantially from one county to another; they cannot be used to classify the counties belonging to this class because they occur in an indiscriminate way. 
- Class 5-Like those in class 2, the counties belonging to class 4 reveal high endowments of human capital. Yet in major opposition, the counties belonging to class 5 present the characteristics of the Western EMP. Women marry later than in any other parts of France. The share of married women is the lowest. The share of women marrying below the age of 25 is twice as low as that in class 2 . The share of definitive celibacy is (with class 3 ) the highest. Counties from class 5 present fertility rates that are below average. The population living in these counties is highly educated and exerts fertility control through marriage. This population is sparse and rural but, unlike that of class 2 , does not benefit from a particularly dynamic industrial sector.

- Class 6-Seine appears a unique county that does not match any of the other five classes. Seine displays the highest endowments in human capital for both men and women. Yet enrollment rates in education are the lowest (together with class 3). Marital fertility is very low but overall fertility is far above national average. Illegitimate births are twice as high as the national average. The density is 30 times higher than the national average and the GDP per capita is by far the highest in France.

The geographical distribution of the classes (Fig. 8) appears astonishingly coherent. Although 25 variables were used to construct the classes, among which many variables appear at first glance to be highly unevenly distributed across the country, very clear geographic classes emerge on the map that visually confirm the importance of the role played by the norms and the culture. The operating forces explaining the location of coherent geographic classes share socio-economic, demographic, and cultural characteristics that are specific to these geographic areas.

Figure 9 presents the position of the French counties along the two main discriminatory dimensions identified by PCA: endowments in human capital (the horizontal axis) and marriage patterns (the vertical axis). Counties displaying a high endowment of human capital are located on the right side of the zero vertical axis; those displaying low endowment on the left side. Counties presenting the characteristics of Eastern EMP are located on the upper side of the horizontal axis; those presenting the characteristics of Western EMP on the lower part of this axis. A clear division appears between our classes 1, 2, 3, and 5 (as summarized in Table 4). On the one hand, highly educated counties (classes 2 and 5) can be identified in contrast to poorly educated counties (classes 1 and 3). On the other, some counties characterized by free marriage practices (classes 1 and 2) may be set against counties controlling the incidence of marriage (classes 3 and 5). Counties from class 4 are not so clearly divided between our two main dimensions. Counties are on average more educated and present the characteristics of the Western EMP, but certain counties composing class 4 do not strictly follow this pattern. ${ }^{17}$

Counties with strong traditions/authoritarian (classes 3 and 5) rely on 'traditional' marriage practices, as described by Hajnal. These counties controlling marriage

\footnotetext{
${ }^{17}$ One major feature of counties composing Class 4 is their dynamic industries. A large share of the population living in these counties worked in the industrial sector, located in densely populated areas. The big cities in these counties were attracting people from other regions in search of jobs. The mixed behaviors and patterns observed in class 4 (as in Seine-Class 6) could be explained by the power of attraction of these urban and industrialized places.
} 


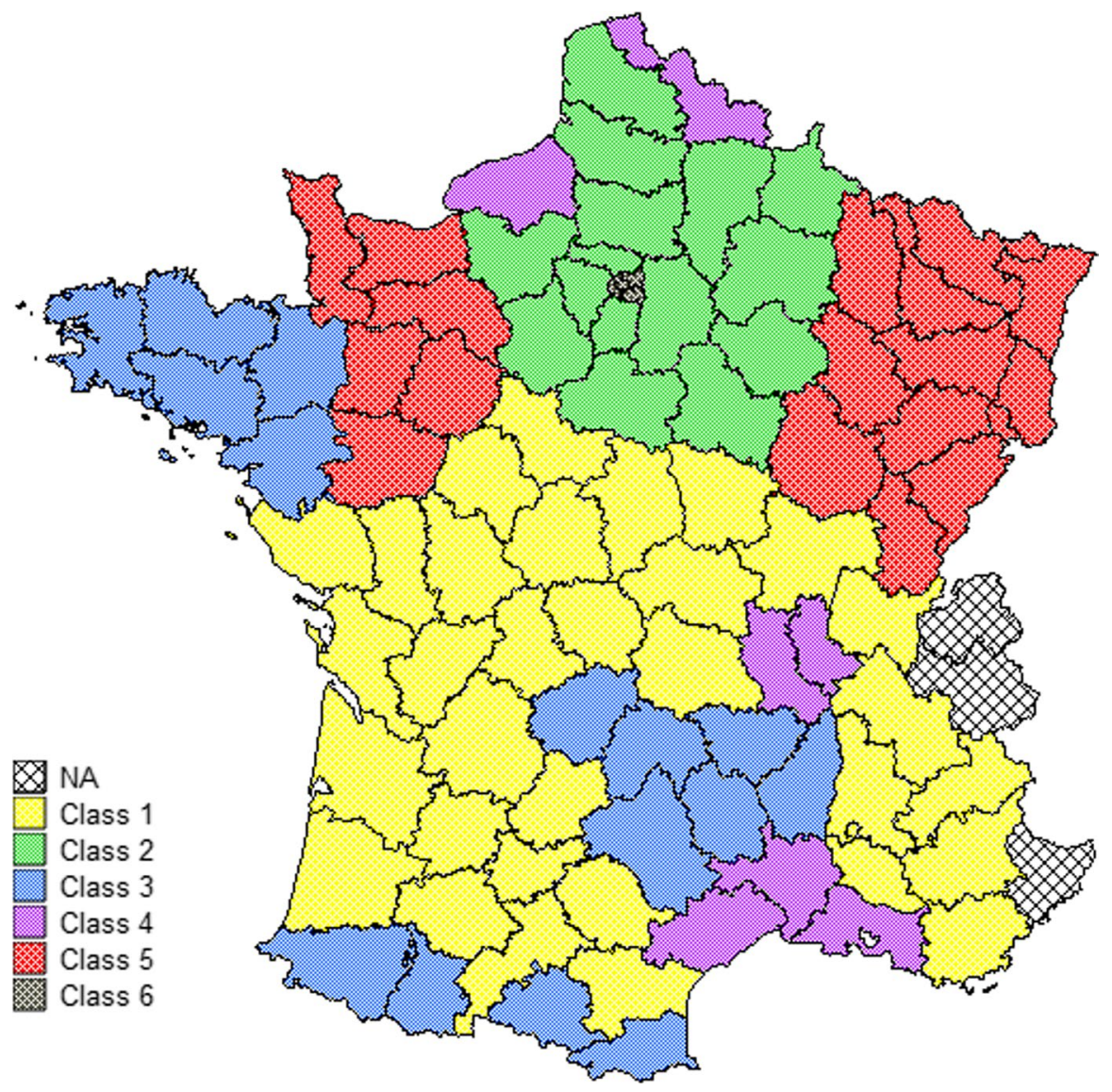

Fig. 8 Geographical Distribution of the Classes

present a low share of married women, late age at marriage, and high celibacy. These counties exhibit the highest marital fertility rates. Class 3 also exhibits some of the highest crude birth rates, in contrast to class 5 in which some of the lowest rates are recorded. Progressive/libertarian counties (class 2), where low importance is placed on religion and traditions, control fertility within marriage and do not exert any control on marriage. They display high shares of married women, a high proportion of early marriage, and low celibacy. Yet these counties-which I call progressive-control fertility within marriage. ${ }^{18}$ Class 2 exhibits the lowest marital fertility and crude birth rates. Class 1 exhibits a similar marriage pattern to that of class 2 . However, counties composing class 1 do not control their fertility within marriage as

\footnotetext{
${ }_{18}$ Micro-level analysis has shown that deliberate control over births occurred in certain areas well before the generalized fertility decline observed from the end of the eighteenth century (see, for instance Perrenoud 1988; Fauve-Chamoux 1991; Eggerickx 2004; Vivier 2014).
} 
much as the counties of class 2 do and crude birth rates remain among the highest. Class 1 is not as economically advanced and successful as class 2 .

In the traditional family economic system, marriage was considered the ultimate control mechanism of fertility (Van de Walle 1986). For Malthus (and contemporaneous authors), the share of single and the age at marriage formed the perfect mechanism for allowing individuals to adjust their fertility ('adaptation mechanisms'). What our findings suggest is that early forms of birth control were used in certain regions to control fertility, in parallel to the traditional 'Malthusian' regulation used in others.

Counties with similar economic structures can display very different demographic patterns. The analysis conducted above shows that the weight of tradition and religious cult triggers different effects in similar (socio-economic) environments. Counties once educated used different means (ways) to attain a similar goal. Counties followed different trajectories, resulting in different timings. Eventually, all counties experienced the demographic transition, but they did not all follow the same trajectory. Culture, norms, traditions, matter profoundly. Accounting for the weight of traditions enables us to better understand the mechanisms (and the puzzles) behind the observed long-run economic and demographic process.

France can be divided into 2 main groups of counties on the basis of their marriage pattern (conservative vs. progressive) and can be divided into two groups on the basis of their fertility ('natural' vs. controlled). These two different divisions point to different situations and outcomes: fertility control within marriage, fertility limitation through marriage control, and natural fertility. If we want to understand the dynamic of the demographic transition, we need to more systematically account for the role played by tradition, culture, norms, and values. Economic development does not inevitably trigger clear-cut changes in a society. The path followed by counties in the process of development is not unique, nor linear. The stickiness of culture and norms explains why it took longer for certain areas in France to experience their fertility transition, despite conducive economic circumstances. The diffusion and spread of fertility control required cultural changes.

\subsection{Cultural beliefs, family structure, and development}

Our analysis shows that the marriage-fertility patterns are more complex than originally described by Hajnal (1965). We have observed the existence of two main types of fertility behavior in the strategy adopted by individuals and households. Fertility regulation can be the result of traditional means of control such as sexual abstinence, delaying first marriage, celibacy, age at first birth. But it can also be the result of 'modern' behaviors consisting in a direct control of the number of births within marriage through spacing out the intervals between births or stopping child-bearing at a certain age (Knodel and van de Walle 1979).

According to the innovation diffusion hypothesis (Carlsson 1966), the fertility transition is the consequence of new behaviors and new knowledge, changes 


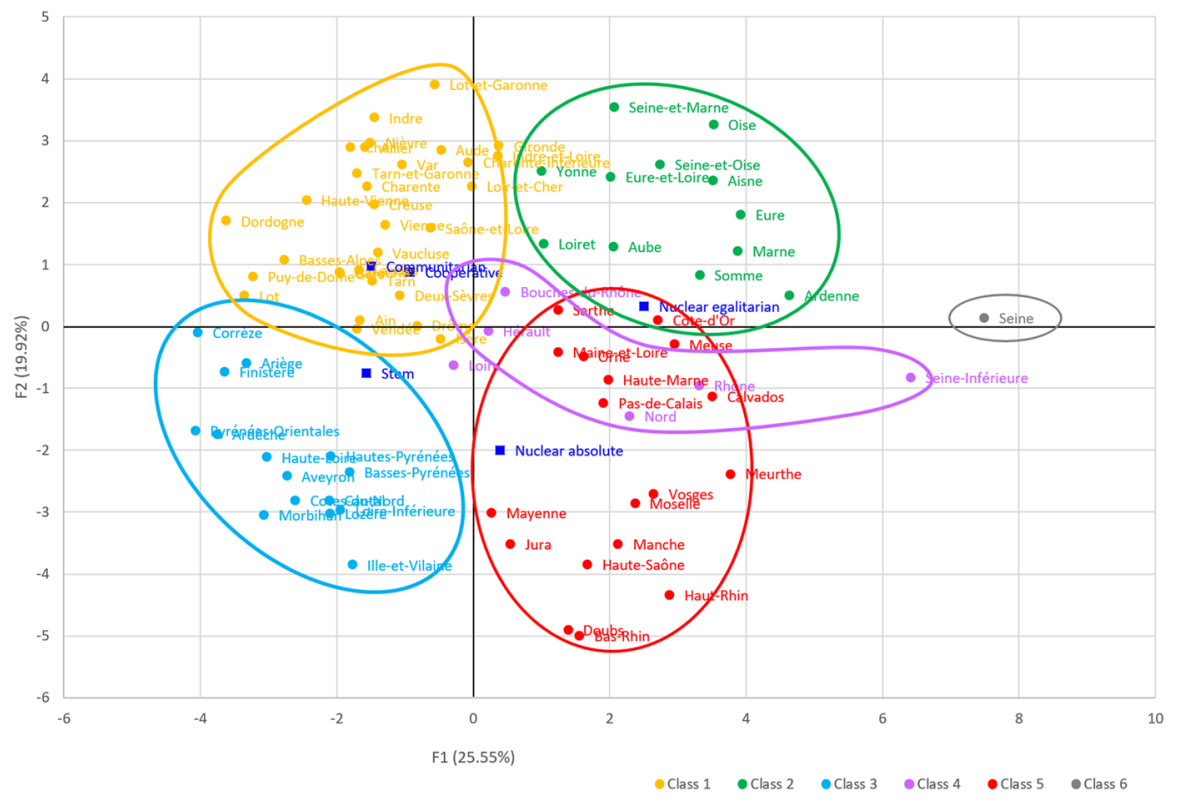

Fig. 9 Position of the Classes on PC1 and PC2

Table 4 Classes on the two main dimensions

\begin{tabular}{lll}
\hline & Poorly educated & Educated \\
\hline Progressive & Class 1 & Class 2 \\
Conservative & Class 3 & Class 5 \\
\hline
\end{tabular}

in culture or attitude toward fertility. For Alter (1992), the fertility transition can be interpreted as 'a shift in the mechanism of population control from restriction of marriage to limitation of childbearing within marriage.' But what triggers this shift? What accounts for the persistence of Malthusian behavior in some counties and the shift to birth control in other counties?

\subsubsection{Family structure and inheritance practices}

Table 5 presents the correlations between our classes and the variables used in our PCA. Significant coefficients at the 5\% level appear in bold. One qualitative variable-family structures-is integrated to our PCA to see how it connects with our typology. France is characterized by the coexistence of diverse family systems and inheritance practices (Berkner and Mendels 1978; Todd 1983, 1990, 2011; Le Bras and Todd 2013). Four main types of family emerge from their libertarian versus authoritarian structure (different parents-children relationships) and their equal versus unequal division of property (between siblings). The types of nuclear family (egalitarian and absolute) are characterized by a liberal relationship between parents 
Table 5 Pearson correlations

\begin{tabular}{|c|c|c|c|c|c|c|}
\hline Variables & Class 1 & Class 2 & Class 3 & Class 4 & Class 5 & Class 6 \\
\hline Marital fertility & -0.162 & -0.240 & 0.549 & 0.087 & -0.127 & -0.178 \\
\hline Crude birth rate & 0.043 & -0.253 & 0.329 & 0.251 & -0.327 & 0.061 \\
\hline Share married women & 0.410 & 0.484 & -0.601 & -0.070 & -0.291 & 0.002 \\
\hline Male age at marriage & -0.302 & -0.484 & 0.409 & -0.034 & 0.386 & 0.095 \\
\hline Female age at marriage & -0.469 & -0.357 & 0.374 & -0.027 & $\mathbf{0 . 5 0 7}$ & 0.086 \\
\hline Early marriage & 0.412 & 0.428 & -0.459 & -0.054 & -0.424 & 0.133 \\
\hline Definitive celibacy & -0.417 & -0.293 & 0.541 & 0.057 & 0.198 & 0.013 \\
\hline Illegitimate birth urban & -0.188 & 0.077 & -0.051 & -0.150 & 0.221 & 0.322 \\
\hline Illegitimate birth rural & -0.296 & 0.219 & -0.211 & -0.109 & 0.389 & 0.171 \\
\hline Infant mortality & -0.089 & -0.266 & 0.231 & 0.153 & -0.046 & 0.226 \\
\hline Male literacy & -0.493 & 0.347 & -0.273 & 0.064 & 0.458 & 0.162 \\
\hline Female literacy & -0.556 & 0.414 & -0.356 & 0.024 & 0.579 & 0.165 \\
\hline Boys' school enrollment & -0.457 & 0.327 & -0.258 & -0.053 & 0.575 & -0.139 \\
\hline Girls' school enrollment & -0.516 & 0.414 & -0.390 & -0.026 & 0.656 & -0.057 \\
\hline Male employed in agriculture & 0.345 & -0.257 & 0.370 & -0.341 & -0.190 & -0.440 \\
\hline Male employed in industry & -0.288 & 0.156 & -0.180 & 0.504 & 0.034 & 0.013 \\
\hline Female employed in agriculture & 0.372 & -0.249 & 0.285 & -0.353 & -0.163 & -0.355 \\
\hline Female employed in industry & -0.247 & 0.108 & -0.167 & 0.523 & 0.007 & -0.006 \\
\hline Civil Constitution of Clergy & 0.287 & 0.332 & -0.378 & -0.019 & -0.272 & 0.056 \\
\hline Inequality in agriculture & 0.247 & -0.229 & 0.175 & -0.092 & -0.182 & -0.067 \\
\hline Density & -0.116 & -0.050 & -0.058 & 0.019 & -0.040 & 0.996 \\
\hline Agglomerated population & -0.159 & -0.094 & -0.173 & 0.530 & -0.089 & 0.615 \\
\hline GGI & -0.525 & 0.194 & -0.286 & 0.083 & 0.626 & 0.160 \\
\hline GDP per capita & -0.218 & 0.423 & -0.436 & 0.310 & -0.027 & 0.467 \\
\hline Nuclear egalitarian family & -0.338 & 0.578 & -0.324 & -0.028 & 0.188 & 0.156 \\
\hline Communitarian family & 0.341 & -0.218 & 0.048 & -0.058 & -0.209 & -0.059 \\
\hline Stem family & 0.191 & -0.262 & 0.243 & -0.099 & -0.145 & -0.070 \\
\hline Cooperative family & -0.025 & -0.112 & -0.007 & 0.419 & -0.143 & -0.030 \\
\hline Nuclear absolute family & -0.233 & -0.121 & 0.086 & -0.090 & 0.368 & -0.033 \\
\hline
\end{tabular}

Values in bold are different from 0 with a significance level alpha $>0.05$

and children, while the types of complex family (communitarian/cooperative and stem) are characterized by an authoritarian relationship between the generations.

In the nuclear egalitarian family, the distribution of inheritance between the children is equal. The equal division of properties induces, a priori, a decline in living standards (or the need to combine working with making a living from other activities). Already, in the seventeenth century, the peasants of the Parisian Basin practiced deeply egalitarian sharing — such as no legislation required (De Brandt 1901). In counties where peasants were dividing their land equally between their children, young people married earlier and established their own family sooner than in regions where lands were held undivided. In contrast to the nuclear egalitarian family, the 
nuclear absolute family is indifferent when dividing the inheritance to the principle of equality between children. The assets and properties are distributed by testament or will and usually go to one single individual, often the eldest or only son.

The communitarian family allows several households to live in the same house. All the sons can marry and bring their wives to the family home. All the brothers inherit equally from their parents. The success of this system depends on the age at which the parents die. In the stem-family system, one child only (usually the eldest) inherits the assets and property of the family (and preserves the lineage). Other children have to leave the family home when they get married but may stay if they remain single. The cooperative family (patrilocal egalitarian) shares strong similarities with the communitarian family. The main difference rests in the temporary nature of the co-residence.

The types of family are projected on the two main dimensions of the PCA in Fig. 9. It illustrates how the family systems relate to the classes. The coefficients of correlation are presented in Table 5. Classes 1 and 3 are positively and significantly correlated with extended types of family. In particular, class 1 correlates with communitarian families and class 3 with stem families. Classes 2 and 5, however, are positively and significantly correlated with the nuclear types (one household per house). ${ }^{19}$ In particular, Class 2 correlates with the nuclear egalitarian type and class 5 with the nuclear absolute type. ${ }^{20}$

\subsubsection{Religious practice}

For the Church, marriage is sacred. Contraception is forbidden and sex is not allowed outside marriage. Yet taking into account the difficulty of life for peasant families and their limited resources (Le Bras and Todd 2013), the Church softened the demographic pressure by allowing women to delay marriage. There is a demographic ideal type of Roman Catholic family characterized by a late age at marriage, high fertility and few illegitimate births. Hence, the rise in illegitimate births together with the decline in the 'traditional' marriage pattern marked a break in religious practices.

After the French Revolution, the government required all clergy to swear an oath of loyalty to the Civil Constitution of the Clergy. Constitutional priests chose to accept the Civil Constitution and to become State workers. This measure aimed at removing Christianity from everyday life in France. As shown in Table 5, Classes 1 and 2 on one side, are significantly correlated with our measure of religious practice

\footnotetext{
${ }^{19}$ Landownership inequality correlates positively with class 2-displaying the highest enrollment in public schools - and negatively with class 1 correlated and with the lowest public enrollments. It confirms the view of Galor et al. (2009) that the egalitarian practice of inheritance may have fostered educational investment.

${ }^{20}$ For complementary literature on the effect of family structures on economic and social behaviors, see Therborn (2004), Greif (2006), Duranton and Rodriguez-Pose (2009), Alesina and Giuliano (2010), Le Bris (2016), Bertocchi and Bozzano (2019), De Pleijt, et al. (2019); Szołtysek et al. (2019) for a nonexhaustive list. For a review of the role of family systems and gender in the fertility transition, see Mason (2001).
} 
proxied by the share of juring priests in 1791, while on the other side classes 3 and 5 are negatively and significantly correlated..$^{21}$ The collapse of clerical institutions in some parts of the country led to the disappearance of the traditional framework of religious life.

Religion matters in understanding how people controlled their fertility. The main difference observed among those who did so lies between individuals controlling their marriage and individuals controlling births (within their marriage). Our findings contradict the linear view that the dechristianization (only) triggered the demographic transition (see Blanc 2020). People living in regions characterized by strong religious practices controlled their fertility as well, but in a more traditional way. Such practices are hidden by the use of variables measuring marital fertility, such as the Ig index developed by Coale and Watkins (1986), as previously argued by Wetherell (2001).

\subsubsection{Gender equality and women's agency}

Classes characterized by greater gender equality and higher investments in girls' (and boys') education display lower fertility. The pattern observed in class 2 is in line with Mendels' (1984) argument that proto-industrialization (and more generally the combination of industrial and agricultural activities) in the countryside may have weakened the Malthusian preventive checks, characterized by late marriage. Yet some nuance should be introduced alongside this argument, as evidenced by the situation of class 5. A major difference between classes 2 and 5 is the level of religious practice. Culture and norms matter (as already argued in the literature, e.g., Bisin and Verdier 2000; Baudin 2010; Alesina et al. 2013; among others). ${ }^{22}$ It can bring different outcomes and explain the differences observed between classes 2 and 5 with regard to their way of controlling fertility: birth control within marriage (class 2) versus control of marriage (class 5).

The literature on gender equality commonly argues that girls' age at marriage is a good measure of the subordination of women in a society. The classic argument is that the increase in human capital delays marriage and gives greater autonomy to girls/women. ${ }^{23}$ Our analysis shows that this is indeed the case in traditional societies (where religious belief and pressure are strong). In such conditions, greater gender equality occurs in parallel to low nuptiality, late marriage, and a high proportion of

\footnotetext{
${ }^{21}$ The share of constitutional priests is commonly used to measure the strength of religious practice. It could also be interpreted as a variable capturing the strength of the revolutionary movement (as well as a variable capturing the cultural proximity to the state and its centralized power in Paris). For Aston (2000), the public oath of loyalty to the Constitution became 'a referendum on whether one's first loyalties were to Catholicism or to the Revolution'.

22 See Alesina and Giuliano (2015) for a literature review of the causal relationship between culture and institutions.

23 As discussed by Carmichael (2011), regions in which women marry earlier and to (much) older men, are regions in which women possess little power. When women marry and have children early, they lose the opportunity to work in the labor market, and lose the incentive to invest in education, unlike women who postpone marriage. What is true for certain periods and countries, as shown by Carmichael (2011), Carmichael et al. (2011), Baten and de Pleijt (2018), de Pleijt and van Zanden (2018), does not match the patterns observed in France at the time of the demographic transition.
} 
individuals remaining single. Yet what our analysis reveals is that in a progressive society (where the pressure of traditions is low), greater gender equality is practiced in environments characterized by active nuptiality, early marriage, and low celibacy.

The characteristics of class 2, combining high education for girls, active nuptiality, early marriage, and low fertility, reflect women's greater decision-making power within the household. ${ }^{24}$ What the characteristics of class 5 reveal is that outside of marriage women's autonomy is possible, but, once married, women lose their autonomy. Late marriage, low nuptiality, and still relatively large marital fertility reflect a lower degree of women's agency within marriage.

Gender equality, as observed in nuclear egalitarian families, fosters economic development. It is not the marriage pattern itself that fosters economic development. It is the level of gender equality, which can take different forms depending on the traditional versus progressive values of the territory where individuals live. Class 2 presents a combination of unexpected characteristics with regard to the conventional literature about marriage patterns and economic development (i.e., sparse and rural population, active and early nuptiality, recourse to birth control).

Different ways of controlling fertility co-existed in mid-nineteenth century France. The different patterns observed between regions cannot be explained as merely a process of diffusion with early and late adopters of fertility control behaviors. They reflect the existence of different strategies of adaptation used by individuals in response to their degree of autonomy/dependence on cultural conventions and norms, and of their degree of adaptation to socio-economic changes. Cultural beliefs and traditional values are (by definition) sticky (Alesina et al. 2013). Changes might ensue more easily/faster in regions that share certain values of change (Rocher 1973) and are more in favor of accepting changes. ${ }^{25}$ The homogenization of behaviors over time certainly offers greater autonomy for people to decide for themselves and keep their distance from cultural conventions.

Class 2 enjoyed the optimal conditions for becoming the cradle of fertility transition (Fig. 10). The long-run trends presented in Sect. 3 suggest that the modern practice of birth control (within marriage) started as early as the eighteenth century and (slowly) diffused itself across France in the course of the nineteenth century. Rural people tended to be more inclined than urban people to choose to restrict their offspring and were thus ahead in terms of birth control. In certain places with high agglomerated population, the growth of industry stimulated fertility. In other places, such as the Parisian Basin, dynamic economic activities and rising living standards went hand-in-hand with birth control. Evidence suggests that these are not stable equilibriums but different forms of evolution with their own repulsive areas and attractive areas (Garden and Le Bras 1988). Ultimately, modern behaviors of fertility control spread to both urbanized and rural areas and led to the unification of the

\footnotetext{
24 As theoretically emphasized by Diebolt and Perrin $(2013,2019)$, women's bargaining power within the household fosters economic growth and offers a better control of fertility with greater investment in human capital.

25 Relying on Todd's classification, Dilli (2016) finds that the nuclear family is associated with higher levels of democracy in the long run.
} 
territory. Hence, two clear phases can be identified in the French demographic transition. Before the mid-nineteenth century, it consisted mainly in a rural phenomenon led by more prosperous districts, with no apparent link between industrialization and urbanization-Paris being an exception (Van de Walle 1986). After 1876, France witnessed a second wave of fertility limitation with the diffusion of modern behaviors to the rest of the country. ${ }^{26}$

The complexity of marriage patterns is likely to explain why Dennison and Ogilvie (2014) found no correlation between female age at first marriage, celibacy rates, household complexity, and economic development. ${ }^{27}$ Our analysis emphasizes the need to improve our knowledge of the long-run evolution of marriage patterns and to more systematically account for changes from a dynamic perspective. The analysis conducted in Sect. 4 shows that greater gender equality and women's agency can occur in the context of active and 'early' marriage. The characteristics of the marriage pattern seem to be highly dependent on cultural beliefs and traditional norms. My analysis suggests that it is not the EMP itself but the greater level of gender equality and women's autonomy (within the household, as long as there is low pressure from religious beliefs) that is at the heart of the positive feedback loop that triggered greater female agency, encouraged female participation in the labor force, increased human capital investment, reduced fertility, and fueled economic growth (Diebolt and Perrin 2013, 2019). The arguments developed by De Moor and Van Zanden (2010) and the elements raised by Dennison and Ogilvie (2014) — that triggered a stimulating discussion - could then be reconciled by (better) accounting for the role played by cultural factors-producing different effects and types of adaptations in different contexts. ${ }^{28}$ In the French context, it seems highly unlikely that the reversal of the marriage pattern-occurring at the same time as the French Revolution and the weakening of the Catholic Church-happened to be a coincidence.

\footnotetext{
26 The diffusion process would then have spread to the rest of Europe (Spolaore and Wacziarg 2014).

27 Dennison and Ogilvie (2014) make the point that 'far from being extreme cases of the EMP, England and the Netherlands manifested moderate demographic patterns. The extremes were found in Scandinavian and central European economies which were much poorer and grew more slowly.' Better economic situations are expected to relax the Malthusian constraint and therefore to be associated with earlier age at marriage. These differences could also find explanations from their cultural specificities. England and the Netherlands are characterized by the primacy of the absolute nuclear family type, while Scandinavian countries, such as Sweden, and countries from Eastern Europe are characterized by the primacy of the stem family. The degree of religious practice is also of key importance for understanding how individuals would behave with regard to fertility control.

28 Extended research remains needed. The analysis conducted at the county level may hide specificities existing within the counties themselves and currently unobserved (such as possible differences in the fertility behavior of urban workers and rural laborers; individuals from different social classes or with different backgrounds). Further research should study this possibility by investigating such relationships at a more disaggregated level, notably using individual-level data.
} 


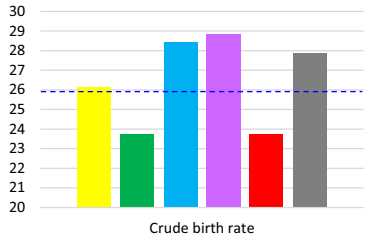

Crude birth rate
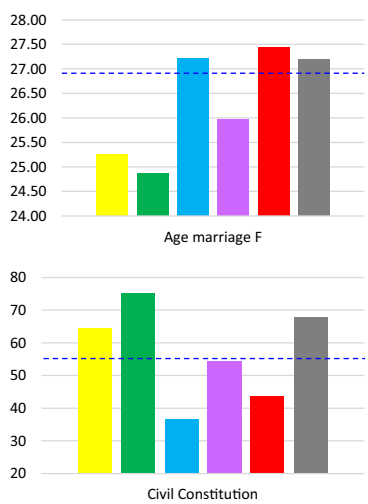

Civil Constitution



Infant mortality



Definitive celibacy

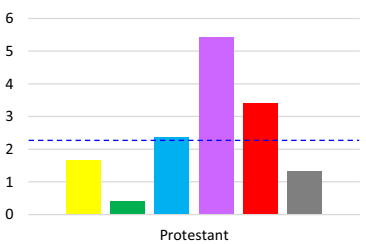

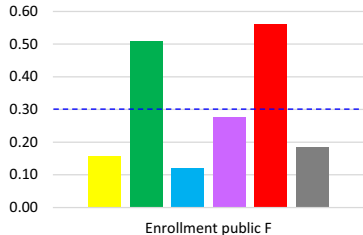
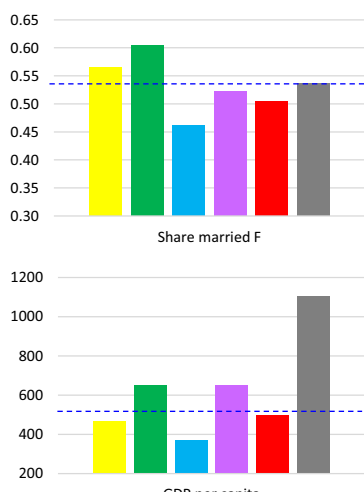

GDP per capita

Fig. 10 Classes-Mean Scores

\section{The spirit of the enlightenment, the revolution, and the status of women}

Why France? Why did the fertility transition start in France about a century before it did in any other European countries? eighteenth century France underwent profound changes: cultural transformation, political revolution, and new economic configurations. The political, mental, and cultural revolutions brought fundamental changes in society and laid the foundations of the transition toward modernity. These revolutions weakened the weight of traditional values and norms in the places that were the most prone to adapt to change.

\subsection{The enlightenment}

Do beliefs and culture matter for understanding the development to modernity and the trajectory followed by countries and regions? Yes, undoubtedly. As shown by the analysis conducted in Sect. 4, in similar circumstances, patterns varied from one region to another. Yet culture is not immutable. The Enlightenment that emerged in Europe in the seventeenth century and dominated the world of ideas during the eighteenth century laid the foundations of what would fundamentally change and broaden our understanding of the world (see Mokyr's (2009) enlightenment theory). 


\subsubsection{The rise of the public sphere-the salons}

France during the eighteenth century was a repressive regime. Yet Paris became the center of philosophic and scientific activity, challenging traditional doctrine. Intellectuals were meeting in the Salons (out of sight) to discuss and remake the world. The salons are of great historical importance (Habermas 1991). Essentially held by women, the salons were most of the time in the homes of well-educated people who came from the bourgeoisie (among the most famous are Madame du Deffand, Madame Lambert, Claudine Guérin de Tencin, Marie-Thérèse Geoffrin, and Suzanne Curchod, known as Madame Necker). ${ }^{29}$ The salons are the places from which the knowledge permeated. The freedom of speech and the concept of equality appeared and gained increasing attention. The salons also enabled the Encyclopedists to present and spread their ideas.

The salons played a positive public role in French society. Women were dominant within them, but their influence did not extend far outside (Roche 1993). Goodman (1996) ignited hot debate surrounding the role of women within the salons and the Enlightenment as a whole. According to him: 'The salonnières were not social climbers but intelligent, self-educated, and educating women who adopted and implemented the values of the Enlightenment Republic of Letters and used them to reshape the salon to their own social intellectual, and educational needs' (Goodman 1996, p. 76).

This phenomenon was not exclusively Parisian. The salons in Bordeaux were active and brilliant, e.g., those of Mme d'Aiguillon, Mme d'Egmont, Mme Duplessy, and Mme de Pontant-Belhade (Didier 1988). Several other French cities welcomed active and dynamic salons held by women: Toulouse, Lyon, Bourg, among others. On the eve of the French Revolution, women played a key role in the diffusion and spread of critical thinking and ideas. According to Didier (1988), the presence of women in the eighteenth century thinking is fundamental and without these women the Enlightenment would not have been what it is.

\subsubsection{The diffusion of knowledge and the ideal of equality}

During the eighteenth century, Paris attracted young intellectuals from the whole country. Denis Diderot is an iconic example. The Encyclopedia which he co-edited with d'Alembert became the symbol of the Enlightenment. The aim of the Encyclopedia was to diffuse knowledge and give everyone access to it. ${ }^{30}$ It was also a way to attack and contest the authority of the Church as part of the battle that set the thinkers of the Enlightenment against religion. In 1749, the Encyclopedia was censored and Diderot was imprisoned for asserting that the knowledge came from the

\footnotetext{
${ }^{29}$ In the age of enlightenment, women were excluded from scientific societies, universities, intellectual professions. Educated women were either self-educated, received education from tutors, or grew up in families with a liberal father.

30 The Encyclopédie, organized as a series of books about the arts and crafts, was interested in ordinary people.
} 
senses and not from divine revelation. The Encyclopedia was a success. It boosted the printing industry and contributed to the propagation of reading skills. All social strata gained access to ideas and information about the vast world. ${ }^{31}$ Various women collaborated to the writing of the Encyclopedia. The philosophical ideas of the Age of Enlightenment were oriented toward progress and to improving the happiness of the greater number of citizens.

Across the eighteenth century, various types of publication and writing highlighted and discussed the role of women in the society, their status, their education (see for instance the writings of Madame de Lambert, Bernardin de Saint-Pierre, Madame Dupin, l'abbé Dinouart, Jean-Francois de la Croix, l'abbé de la Porte, l'abbé Riballier, Madame d'Epinay, Madame de Coicy, etc.). ${ }^{32}$ Criticizing the traditional roles for women, Louis de Jaucourt-who wrote a number of articles on women in society for the Encyclopedia-discussed the weaknesses of the reasoning that the husband's rule has its source in nature. He argued that such a principle was contrary to natural human equality: 'a man does not invariably have more strength of body, of wisdom, of mind or of conduct than a woman' ('Femme' in Encyclopedia).

The philosophers of the Enlightenment on grounds of traditional morality present women's education as a fundamental prerequisite for escaping the condition of dependence they had been locked into (see Jolibert 2007). Condorcet is the emblematic figure embodied behind these ideas. He was a pioneer in the fight for women's rights (the enfranchisement of women to the City's rights). He was convinced that a society without gender equality is a flawed society that deprives itself of progress and condemns itself to mediocrity. For him, the easiest way to guarantee this equality was to provide quality public education to every child without gender distinction. In his 'Essai sur la constitution et la fonction des assemblées provinciales' (1788), Condorcet wrote that 'Women must receive the same education as men: this way they will better educate their children and the family will win on balance by a greater equality between its members.' ${ }^{33}$ Mathematician and partisan of the Enlightenment's ideas, Condorcet believed that mathematics could help build a fairer society.

The Age of Enlightenment is characterized by the desire for a deep change of society in a scientific and rational way. The Enlightenment contributed to the diffusion of knowledge, with the core ambition to gain freedom of expression and other fundamental freedoms. The battles of ideas and values between the great thinkers of the Age of Enlightenment and the Church have shaped the world in which we now live. The Enlightenment, and its continuity the French Revolution, upheld ideals of liberty, progress, fraternity, and equality, and undermined the authority of the Catholic Church.

\footnotetext{
31 See Squicciarini and Voigtländer (2015) for an empirical investigation of the specific role played by scientific elites, proxied by subscriptions to the Encyclopédie, on the adoption and diffusion of modern technology.

32 See Jolibert (2007) for a detailed presentation of the content of these writings.

33 Before Condorcet, Diderot, Thomas and Madame d'Epinay raised the discussion on the status of women and equality between the sexes (see for instance the essay Sur les Femmes, 1772). And as early as the Renaissance, opinion was being stirred up in favor of educating girls in France (Fleury, 1687; Fénélon, 1687).
} 


\subsection{The French Revolution}

Women have often been left out of our representation of the events that triggered the French Revolution. A few figures emerge (Olympe de Gouges, Théroigne de Mericourt, Madame Roland, Madame de Staël, Pauline Léon, etc.) but too often the role of the female revolutionary crowd is left aside. But women did take part in the French Revolution. They were present and active before the Revolution was set in motion and throughout its process (see Mazeau and Plumauzille 2015, for a historiography of the role of women in the French Revolution). Women's participation in the Revolution was from the first a massive and multi-dimensional phenomenon (Devance 1977).

\subsubsection{Women during the French revolution}

The official convocation of the Estates General (general assembly representing the clergy, the nobility, and the third Estate) by King Louis XVI in January 1789 summoned French people to discuss and deliberate on the purpose of electing their representative and of conveying their 'remonstrances, complaints, and grievances' directly to the king. This process resulted in the writing of 60,000 books from all provinces of France that were intended for use in suggesting reforms.

Women took an active role in drafting the registers of grievances ('Cahiers de plaintes et de doléances'). Although most of the writings were signed by men, women's grievances played a part in the content and represent a continuity with the Age of Enlightenment (see Fauré 2006). Among the main complaints were, among other things, the lack of primary education for women, their situation of economic dependence on men, the need for midwives' education, the creation of State manufactures offering jobs to both men and women, and the right to divorce. For Chassin (1863), the claims raised by the Cahiers reflect and confirm the existence of a feminist movement that flew through the Revolution.

Women were present and participated actively during various key events of the Revolution. Women, armed with stones, sticks, and bars, took part in the Day of the Tiles-a riot in Grenoble in June 1788. They intervened in a number of violent riots and demonstrations during the spring of 1789. Alongside men, women participated to the Storming of the Bastille on the July 14, 1789.

The October Days are among the most significant events of the Revolution. On October 5, 1789, market-women gathered on the Place de Grève and started demonstrations against the high price and scarcity of bread. ${ }^{34}$ Under heavy rain, a group of women decided to march on Versailles (the king's residence and the location of the Assembly) to protest against the scarcity of food. Seated on the bench of the Assembly between the deputies, women took over the gallery and asked for bread and grain. The marchers succeeded in forcing the king to move to Paris and support the reforms. On the way back to Paris, on October 6, a crowd of about 60,000 people

\footnotetext{
34 See Sharp and Weisdorf (2012) for a discussion on the roots of the French Revolution and economic conditions faced by French workers in the centuries preceding it.
} 
escorted the royal family and one hundred deputies to the capital. This event marked a major turning point in the French Revolution. ${ }^{35}$

Women's clubs (somewhat similar to the salons during the Enlightenment) are another clear example of women's political involvement during the Revolution. Two clubs succeeded each other in Paris: the 'Société patriotique des Amies de la vérité' (1791-1792), founded by Etta Palm d'Aelders, and the 'Club des Citoyennes Républicaines Révolutionnaires,' formed in May 1793 (Godineau 2011). These clubs were composed of ordinary women, e.g., grass-roots campaigners, merchants, seamstresses, workers, among others. Women belonging to these clubs discussed a number of topics related to girls' education, political rights, votes for women, citizenship, civil majority, divorce, access to civil and military jobs, etc. These Clubs were not just a Parisian feature. Women's clubs were created in a number of cities: Arles, Besancon, Bordeaux, Dijon, Lyon, among others.

The 'tricoteuses' (knitting women), seated in the spectators' gallery of the National Convention, attended and participated in the sessions of the Assembly. Women in the Assembly_while knitting-continually commented, booed or applauded the decisions taken to put pressure on the deputies (see Godineau 1988). Another major indication of the presence of a feminist movement in France catalyzed by the French Revolution is undoubtedly Olympe de Gouges' Declaration of the Rights of Women and of the Female Citizen in 1791, whose Article 1 states that 'Women are born and remain free and equal in rights to men.'

\subsubsection{Major breakthrough for gender equality (?)}

Feminism emerged alongside claims for social and political change to promote greater equality. The movement was deeply weakened with the abolition of women's clubs in October 1793 (after the radicalization of the revolutionary movement) ${ }^{36}$ and the implementation of the Napoleonic Code in 1804 that pushed women back to second-class status (Abray 1975). After heated debates and hesitations, women did not get access to political rights. Still, a set of crucial laws was implemented by the National Assembly during the Revolution and contributed to changes in the status of women within the family as well as in society.

\subsubsection{Gender within the family}

A set of incremental laws brought changes in gender relations within the family. ${ }^{37}$ In 1791, the Constituent defined in identical terms access to the civil majority for

\footnotetext{
35 See the works of Michelet (1855), Duhet (1977), Godineau (1988, 2015), Le Bozec (2019) for more details about the active role played by women during the French Revolution.

${ }^{36}$ The decree Amar prohibited the right of association for women, their presence in the Assembly, meetings of more than 5 women, henceforth closing the door to political life for women-which Amar qualified as being 'incompatible with the sweetness and restraint that make the beauty of their gender' (see Duverger 1872).

${ }^{37}$ See chapter 5 of Ourliac and Malafosse (1968) for a history of private and family law from the Middle Age to the Napoleonic Civil Code.
} 
men and women. The year after, the law deconsecrated marriage so that it became a contract between spouses.

On September 20, 1792, divorce was established by law. It recognized equality between spouses, as well as divorce by mutual consent. Men and women could divorce on equal terms, and remarry. Divorce was implemented first in France, long before any other country. ${ }^{38}$ This very liberal law was modern and unique for the time - far ahead of all foreign legislation of the time. One had to wait for the twentieth century to see the implementation of such liberal laws in the rest of Europe and North America (Phillips 1979). These laws in France established a strict symmetry between men and women (the same procedures, rights, and duties). They changed the perception of marriage from being an end in itself to a way to achieve happiness. The law gave women more liberty to decide for themselves and stopped them falling automatically under the control of their husband. ${ }^{39}$

The striking figure of this law is the equality that it introduces between genders. It offers both spouses exactly the same right to obtain a divorce (and the court costs were negligible). ${ }^{40}$ Comparing this law to what was happening in other countries clearly shows the revolutionary characteristics of the French law. It gave both spouses the possibility of divorce and was accessible to rich and poor, for any type of reason without requiring proof in cases of incompatibility of temperament and character, only the simple determination of one spouse to obtain a divorce. This law gave spouses almost complete freedom to divorce. Restrictive pressures could come not from the law but from society itself (Phillips 1979).

After the implementation of the law, the number of divorces to be granted was relatively high at first but slowed down in the years following. In the places for which data are available, it appears that women sought divorce much more frequently than men $\operatorname{did}^{41}$ and that the rate of divorce was much higher in cities than in the countryside ${ }^{42}$ (Phillips 1979). Women used the unilateral divorce law much more often than men did. To divorce by mutual consent, the spouses had to jointly ask for

\footnotetext{
38 The law was modified in 1793 and 1794, and incorporated in the Civil Code. The French Civil code permitted divorce for 4 different reasons; mutual consent (which comprises over $60 \%$ of all divorces); acceptance; separation of 2 years; and due to the 'fault' of one partner (accounting for most of the other 40\%). The law was abolished in 1816 during the Bourbon Restoration when the Catholic Church was restored as the State religion. It was not until July 1884, under the Third Republic, that divorce was restored with the implementation of the law Naquet.

39 For Stanton (1898), divorce was not simply a right under gender equality; it enabled women to enforce their own vision of marriage and transforms this relationship into something more egalitarian.

${ }^{40}$ In England, for instance, getting divorced was very expensive (divorce by private act of Parliament cost 800 livres in the nineteenth century and valid reasons for divorce were very limited and the privilege of the husband. It was so difficult to divorce that between 1715 and 1852 only 184 divorces were pronounced in the whole country (and only 4 by women) (Phillips 1979). The law changed in 1857.

41 Toulouse-Haute-Garonne: Women asked for $65 \%$ of unilateral divorces (i.e., $71 \%$ of the divorces for ascertained motives); Metz-Moselle: 73\%; Rouen-Seine-Inférieure: $71 \%$ (77\% of the divorces for ascertained motives, in most cases because of domestic violence, and also for absence and abandonment).

${ }^{42}$ In Rouen (Seine-Inférieure), for instance, divorces in cities were about 4 to 5 times as frequent as those in the countryside (with similar nuptiality; but without information about the age distribution of the population).
} 
divorce. If one of the spouses refused to give it, the other spouse could make a unilateral demand. The preponderance of women asking for a divorce may reflect the empowerment of women that was made possible by this law. Traditionally, women had been legally and socially inferior to men. During the Ancien Régime, a woman who married became dependent on her husband. He had a dominant role in the family; his wife needed his approval for every major act. He held marital authority and absolute control of his family.

Divorce was concentrated in cities, but rather low numbers of people in the countryside. Possible explanations are that cities were more open to revolutionary ideas; cities saw a greater weakening of religious authority; cities held more opportunities for (divorced) women. Concerning the last of these possible explanations, the living conditions hold a clue. After divorce, without the help of an extended family, people have two key requirements: a home and a job. These two were probably easier to get for women living in cities, since urban proto-industrialization/textile industries offered women opportunities to work (in Rouen, for instance, $97 \%$ of women asking for a divorce were employed in the textile industries, as daily workers, domestics, or merchants), and a furnished room in a hostel, a boarding house, or on its own could be rented.

In 1793, the male birthright was abolished. Every child became equal in succession/inheritance irrespective of its birth rank or gender. The National Constituent Assembly pushed forward women's autonomy by the implementation of this measure and henceforth by abolishing male privilege. The law established in June 1793 granted women (aged 21 or older) the immediate right to vote at the municipal general assembly elections for a representative who would decide on the distribution of municipal properties and their practicalities (Bourgin 1908). ${ }^{43}$ Mothers obtained the same right as fathers to manage the affairs of their beneficiary under-age children (Aberdam 2005). Simultaneously, the committee of public assistance adopted a law under which poor families, widows, old people, unmarried mothers, and abandoned children could receive assistance.

\subsubsection{Gender and education}

Another (underreported) law reflects the fundamental changes in the way that women's role in society was perceived. Various heated discussions enlivened the Assembly between 1792 and 1793. Among them is the discussion about public education. In 1792, Romme reported on public education, relying on Condorcet's arguments and defending the access of girls to republican schools. In June 1793, the question of public education was on the agenda of the Convention. Lakanal presented a report in which article 1 states that 'the purpose of national schools is to offer children of both genders the education required by French citizens.' Lakanal's project gives a

\footnotetext{
43 Aberdam (2005) emphasizes the existence of various documents reflecting the participation of women (in particular single women and widows) in elections, via their presence on lists of citizens having the right to vote over the period 1789-1792, as well as their presence and interventions as mentioned in the minutes of the primary assemblies.
} 
mandatory status to girls' primary education. Despite heated debates following the presentation of the project, on October 26, 1793, the first decree establishing primary education mentions that girls will receive the same education as boys (with the additional specification: 'as much as their sex allows'). On December 19, 1793, the decree Bouquier (almost a century before the Ferry laws) established compulsory, public, and free education (for at least three consecutive years) for boys and girls (teachers' remuneration being paid by the State). The content of education is free. The only criterion is that it should respect the principles of the Republic. No difference is made between boys and girls.

This decree reflects the recognition of the incremental role played by women in transmitting norms and values to children. ${ }^{44}$ The ultimate goal of the Convention is to give a republican education to girls who will transmit these values to the next generation-the future citizens of the Republic. To ensure a republican education for all, it becomes crucial to create public schools; this will free women from the influence of the Church and put them at the service of the Republic (see Fayolle 2013 , 2014). Social norms can be changed through political education. Public education aims at making boys and girls capable of thinking for themselves and echoes the Universalist ideals derived from the Age of Enlightenment that education can trigger equality. As early as January 1793 (i.e., before the implementation of the decree), schools for girls were spontaneously created by mandated representatives and by women's societies and clubs. ${ }^{45}$

Reforming the legislation about the family was one of the tasks of the revolutionary legislators over the period 1789-1792. In addition to the divorce law, the legislation introduced the principle of equality in inheritance; reduced the legal age of majority from 25 to 21 years old, and offered a marital status to women that gave them more rights over themselves and their property. At the end of the eighteenth century deep changes affected the family - the key and primary institution of society. The new laws weakened the bases of traditional marital authority; it changed the relations between men and women, and between parents and children. The combination of heated debates about the importance of educating boys but also girls, and the secularization movement triggered changes in the mentality of France-a process that had been emerging since the middle of the eighteenth century (Vovelle 1977). Women did not gain the right to vote, but they gained freedom of expression and opinion. This period has marked some changes for women. Despite some progress, the condition of women only partially improved. The Revolution has not been, strictly speaking, a breakthrough for women but it conferred civil equality and social empowerment for women. It contributed to weaken the Church and accordingly contributed to weaken the weight of traditional beliefs and values in society.

\footnotetext{
44 'Men make laws, women make customs,' In Le connétable de Bourbon (1785) Act I., Sc. IV, JacqueAntoine-Hippolyte de Guibert (1786).

45 The district reports show regional disparities. Enrollments were larger in big cities. At the end of 1793, France counted 150 female school teachers and 3952 girls enrolled in schools. By 1794, these numbers had increased by 50\% (Fayolle 2013). In 1802, girls' schools as a separate category disappeared from the general law on primary instruction. Although this modification of the law heralded the closure of public schools for girls, women's voices continued to be heard and resistance persisted.
} 
Yet mentality and attitudes are sticky. Not every region of France adhered to the revolutionary changes and the reforms implemented to dissolve the Catholic Church. It took more time for these changes to spread to the more traditionally anchored societies and may explain the regional diversities observed across France (as well as temporary periods of revival for traditional values).

\section{Conclusion}

Chesnais (1992) defines the demographic transition as 'a logical succession of historical phases through which every population passes in the movement towards modernity.' If this definition is widely accepted, then the puzzles, inconsistencies, and challenges inherent in the process keep the debate active around its dynamics, underlying factors, and origins. Among the crucial challenges is France. France is commonly described as an unual case. This may be so, but the description perhaps misses crucial ingredients and contributes to hamper our understanding of the dynamics governing fertility behaviors.

In this paper, I have questioned the origins of the demographic transition and tried to explain why it started in France. The investigation of marriage patterns in the long run reveals that the fertility transition occurred at the same time as the decline in the traditional marriage pattern, as originally described by Hajnal. Before the French Revolution, marriage practices were characterized by a large share of definitive celibacy and by marriage late in life. After the French Revolution, this pattern is reversed. The share of definitive celibacy falls sharply, while the median age at marriage takes an impressive downward path. This surprising and counterintuitive finding forces us to reconsider our understanding of fertility behaviors in the past.

During a large part of the eighteenth century, French people acted authentically in a Malthusian way. At the turn of the nineteenth century, they started increasingly to rely on modern strategies of fertility by controlling births within marriage. How can this evolution be explained? The analysis of regional diversity through the use of exploratory methods helps us to answer this question. The analysis reveals the co-existence of different socio-economic and cultural profiles across France (at a crucial time of the process, during which counties had reached different stages of it). Four main classes emerge. The main bases of the classification are the type of marriage pattern and the level of human capital. Beyond these two dimensions, religious practice, family systems, and gender relations appear as crucial determinants of fertility behaviors.

Counties where strong traditional values and cultural beliefs are entrenched rely on the classical marriage pattern to control fertility. Progressive counties, however, control fertility within marriage and present the characteristics of what I call a progressive marriage pattern. The counties that combined progressive (and secular) ideals and high investment in education enjoyed the optimal conditions for engendering the fertility transition. In addition, they show the highest 
economic performance (after the capital region of Paris). ${ }^{46}$ Social, economic, and cultural contexts are incremental for understanding the geographical differences observed across France. These multiple dimensions must be taken into account to understand the dynamics of each region's trajectory (and, therefore, that of each country).

My findings have theoretical and empirical implications. The paper contributes to various strands of the literature. First, it enters the debate on the effect of the EMP on economic development. The literature linking the EMP and economic development tends to assume that the EMP was stable and consistent over time, and varied only under specific economic circumstances. I show that this assumption should be taken with caution and that more extensive investigations are needed of the dynamics of the marriage pattern in the past. The French case teaches us that the marriage pattern was not as stable and homogeneous as one might have thought prima facie. The French pattern suggests that women can gain greater equality within marriage as revealed by the transformations of the marriage pattern to one of low celibacy, low age at marriage, and low fertility. Female empowerment is genuine and effective if it can proceed within the household and not only by postponing marriage. Equality is real when the voices of both partners can also be heard within the household.

Second, the paper contributes to the literature on the role played by culture, norms, and ideology in shaping the development process. The French Revolution brought substantial changes to French communities. Progressive beliefs in favor of equality were institutionalized through the implementation of various laws that were also beneficial to women (e.g., by stipulating an equal inheritance system, divorce, education). The societal changes that occurred at the time of the Revolution (and that have their roots in the age of enlightenment) transformed France. The typology of French counties shows the coexistence of progressive and conservative behaviors. The stickiness of cultural beliefs in more traditional places made them less prone to accept societal changes and explains why they took longer to adapt to these changes.

The coexistence of a variety of patterns, as observed in the French case, shows the importance of being cautious and attentive to such a possibility. Looking at average individual behavior hinders us from capturing the diversity of behaviors. It may produce misleading or inconclusive results that prevent us from properly identifying and interpreting the dynamics behind historical processes, such as the demographic transition. An underlying learning outcome of our analysis is the need to use indicators of marital fertility with caution. Places with strong traditional values are more willing to control fertility through nuptiality. Yet, once married, fertility within marriage may remain active. To capture the full picture one must also account for the proportion of individuals who get married and the share of individuals who remain single.

\footnotetext{
${ }^{46}$ Perrin (2021) provides empirical evidence of the association of gender equality and family systems with economic development, and confirms the relevance of the association as identified by exploratory methods.
} 
Further research is needed to improve our understanding of fertility behaviors in the movement toward modernity. Extended research should notably be conducted at more granular levels and from comparative perspectives. How did marriage patterns evolve in other European countries at the time of their fertility transition? Did they experience a similar transformation to that observed in France? If a major cultural breakthrough, symbolized by the spread of secularization and intellectual movement, was diffused from France to the rest of the Continent, then similar patterns to the one witnessed in France-of declining age at marriage, decreased rates of celibacy and increased marriage-should be observed elsewhere.

\section{Appendix}

See Fig. 11 and Table 6

(a)

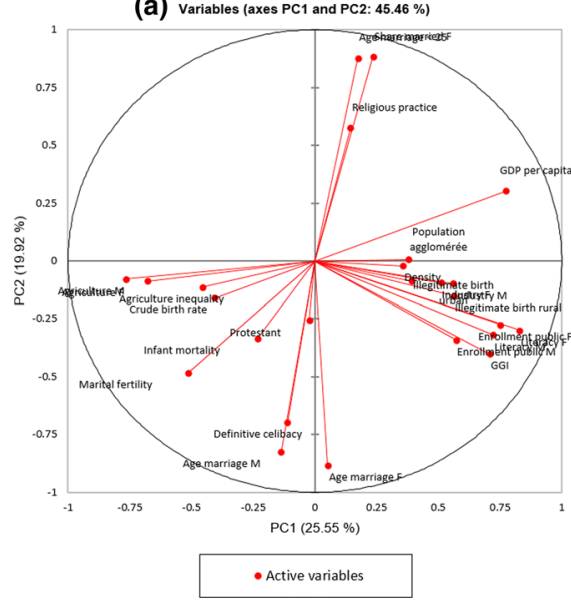

(b) Variables (axes PC1 and PC3: $37.71 \%$ )

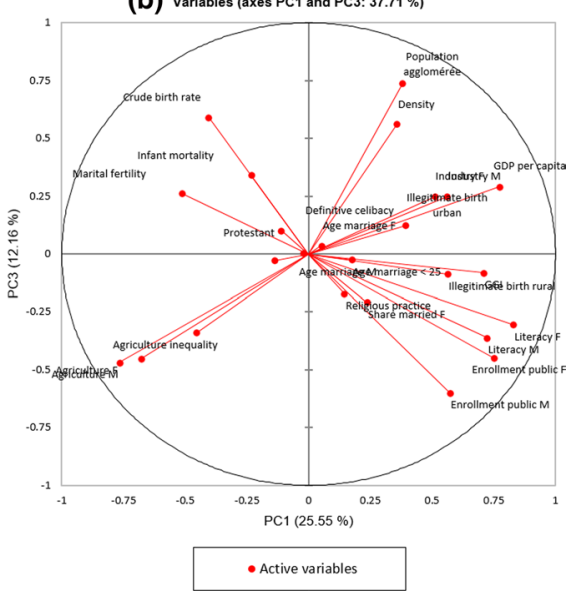

Fig. 11 Correlation Circle 
Table 6 Description of the variables

Name of the variable

Demographics

Marital fertility rate

Crude birth rate

Share married women

Male age at marriage

Female age at marriage

Early marriage

Illegitimate birth urban

Illegitimate birth rural

Definitive celibacy

Infant mortality

Education

Boys school enrollment

Girls school enrollment

Male literacy

Female literacy

Economic

Density

Agglomerated population

Female employed in agriculture

Female employed in industry

Male employed in agriculture

Male employed in industry

Landownership inequality

GDP per capita

Socio-cultural

Protestants

Civil Constitution of Clergy

Gender gap index

Family structure
Description of the variable

Share of new born per married women in age of childbearing (15-45), 1851

Share of birth over total population, 1851

Share of married women per women in age of being married, 1851

Men average age at marriage, 1855

Women average age at marriage, 1855

Share of women who married young $(<25$ years old) per married women, 1851

Share of illegitimate births over total number of births in urban areas, 1851

Share of illegitimate births over total number of births in rural areas, 1851

Share of women who are still single after age 50, 1851

Mortality at age 0,1851

Share of boys enrolled in public primary schools per number of boys aged 5-15, 1851

Share of girls enrolled in public primary schools per number of girls aged 5-15, 1851

Share of men able to read and to write, 1861-1865

Share of women able to read and to write, 1861-1865

Number of people per $\mathrm{km}^{2}, 1851$

From Statistique Générale (towns populated of min 2000 inhabitants), 1851

Share of women employed in agriculture over total number of women aged 15-60, 1851

Share of women employed in industry over total number of women aged 15-60, 1851

Share of men employed in agriculture over total number of women aged 15-60, 1851

Share of men employed in industry over total number of women aged 15-60, 1851

Share of landowners, 1851

Gross value added per capita, 1860 (Caruana-Galizia 2013)

Share of Protestants per total 100 people, 1861

Share of juring priest (Tackett 1986)

Composite index of gender equality (Perrin 2014)

Family types (Le Bras and Todd 2013)

The variables are built using various sources from the Statistique Générale de la France: Résultats Statistiques du Dénombrement (1851); Territoire et Population, 1851; Mouvement de la Population 1851, 1854; Statistique agricole de 1852; Industrie, résultats généraux de l'enquête effectuée dans les années 1861-1865; Statistique Comparée de l'Enseignement Primaire, 1829-1877 
Acknowledgements I am deeply grateful to Prof. David Le Bris for his thorough reading of the paper and valuable comments and suggestions that contributed to improve the content of the paper. I am also very thankful to the anonymous referees for their careful reading, constructive comments, and additional references provided.

Funding Open access funding provided by Lund University.

Open Access This article is licensed under a Creative Commons Attribution 4.0 International License, which permits use, sharing, adaptation, distribution and reproduction in any medium or format, as long as you give appropriate credit to the original author(s) and the source, provide a link to the Creative Commons licence, and indicate if changes were made. The images or other third party material in this article are included in the article's Creative Commons licence, unless indicated otherwise in a credit line to the material. If material is not included in the article's Creative Commons licence and your intended use is not permitted by statutory regulation or exceeds the permitted use, you will need to obtain permission directly from the copyright holder. To view a copy of this licence, visit http://creativecommons.org/licen ses/by/4.0/.

\section{References}

Aberdam S (2005) Deux occasions de participation féminine en 1793: le vote sur la Constitution et le partage des biens communaux. Annales Historiques De La Révolution Française 339:1-16

Abray J (1975) Feminism in the French revolution. Am Historical Rev 80(1):43-62

Alesina A, Giuliano P (2010) The power of the family. J Econ Growth 15:93-125

Alesina A, Giuliano P (2015) Culture and institutions. J Econ Lit 53(4):898-944

Alesina A, Giuliano P, Nunn N (2013) On the origins of gender roles: Women and the plough. Q J Econ 128(2):469-530

Alter G (1991) New perspectives on European marriage in the nineteenth century. J Fam Hist 16(1):1-5

Alter G (1992) Theories of fertility decline: a nonspecialist's guide to the current debate. In: Gillis JR, Tilly LA, Levine D (eds) The European experience of declining fertility. Blackwell, Cambridge, MA, pp 1850-1970

Aston N (2000) Religion and Revolution in France, 1780-1804. Catholic University of America Press, Washinton, DC, Macmillan Press, London

Baten J, De Pleijt A (2018) Female autonomy generates superstars in long-term development: evidence from 15th to 19th century Europe, CEPR Discussion Paper No. DP13348

Baudin T (2010) A role for cultural transmission in fertility transitions. Macroecon Dyn 14(4):454-481

Bengtsson TM, Dribe, (2006) Deliberate control in a natural fertility population: southern Sweden, 17661864. Demography 43(4):727-746

Berkner L, Mendels F (1978) Inheritance systems, family structure and demographic patterns in Western Europe. In: Tilly C (ed) Historical studies of changing fertility. Princeton, Princeton University Press, pp 209-223

Bertocchi G, Bozzano M (2019) Origins and implications of family structure across italian provinces in historical perspective. In: Diebolt C, Carmichael S, Dilli S, Rijpma A, Störmer C (eds) Cliometrics of the family: global patterns and their impact on diverging development. Studies in Economic History. Springer, Berlin, pp 121-147

Bideau A (1983) Les Mécanismes Autorégulateurs des Populations Traditionnelles. Ann Econ Soc Civil 5:1040-1057

Bignon V, Garcia-Penalosa C (2016) Protectionism and the education-fertility trade-off in late $19^{\text {th }}$ century France, Working papers halshs-01264614, HAL

Birdsall N (1983) Fertility and economic change in eighteenth and nineteenth century Europe: a comment. Population Dev Rev 9(1):111-123

Bisin A, Verdier T (2000) 'Beyond the melting pot': cultural transmission, marriage, and the evolution of ethnic and religious traits. Q J Econ 115(3):955-988

Blanc G (2020) Modernization before industrialization: cultural roots of the demographic transition in France, HAL archives-ouvertes, hal-02318180v6 
Bonneuil N (1997) Transformation of the French demographic landscape 1806-1906. Clarendon Press, Oxford

Bourdelais P (1997) Épidémies et population : bilan et perspectives de recherches", In: Annales de Démographie Historique, pp 9-26

Bourgin G (1908) L'agriculture. Instruction, recueil de textes et notes, Bulletin de la Commission pour la recherche et la publication des documents d'histoire économique de la Révolution française, 3 et 4 , Imprimerie nationale

Braudel F (1990) L'identité de la France. Espace et histoire, Paris, Champs-Flammarion

Brée S, de la Croix D (2019) Key forces behind the decline of fertility - lessons from childlessness in Rouen before the industrial revolution. Cliometrica 13:25-54

Burguière A (1972) De Malthus à Max Weber : le mariage tardif et l'esprit d'entreprise. Ann Econ Soc Civil 27(4-5):1128-1138

Carlsson G (1966) The decline of fertility: innovation or adjustment process. Popul Stud 20(2):149-174

Carmichael SG (2011) Marriage and power: age at first marriage and spousal age gap in lesser developed countries. Hist Fam 16(4):416-436

Carmichael SG, van Zanden JL, de Moor T (2011) When the heart is baked, don't try to knead it: marriage age and spousal age gap as a measure of female 'agency, Working papers 0019, Utrecht University, Centre for Global Economic History

Carmichael SG, De Pleijt A, van Zanden JL, De Moor T (2016) The European marriage pattern and its measurement. J Econ History 76(1):196-204

Caruana-Galizia P (2013) Estimating French regional income: departmental per capita gross value added, 1872-1911. Res Econ Hist 29:71-95

Chassin C-L (1863) Le génie de la Révolution, les élections de 1789. Pagnerre, Paris

Chesnais JC (1992) The demographic transition: stages, patterns, and economic implications. Clarendon Press, Oxford

Chilosi D, Murphy TE, Studer R, Coşkun Tunçer A (2013) Europe's many integrations geography and grain markets, 1620-1913. Explor Econ History 50(1):46-68

Coale AJ, Watkins SC (1986) The decline of fertility in Europe. Princeton University Press, Princeton, NJ

Condorcet JAN (1788) Essai sur la constitution et la fonction des assemblées provinciales, Archives de la Révolution Française.

De Brandt A (1901) Droit et coutumes des populations rurales de la France en matière successorale, Librairie de la Société du Recueil général des lois et des arrêts, Paris

De la Croix D, Perrin F (2018) How far can economic incentives explain the French fertility and education transition? Eur Econ Rev Elsevier 108:221-245

De la Croix D, Schneider EB, Weisdorf J (2019) Childlessness, celibacy and net fertility in pre-industrial England: the middle-class evolutionary advantage. J Econ Growth, Springer 24(3):223-256

De Moor T, Van Zanden JL (2010) Girl power: the european marriage pattern and labour markets in the north sea region in the late medieval and early modern period. Econ History Rev 63:1-33

De Pleijt A, van Zanden JL (2018) Two worlds of female labour: gender wage inequality in Western Europe, 1300-1800", EHES Working paper, Paper No. 138.

De Pleijt A, van Zanden JL, Carmichael SG (2019) Gender relations and economic development: hypotheses about the reversal of fortune in Eurasia. In: Diebolt C, Carmichael S, Dilli S, Rijpma A, Störmer C (eds) Cliometrics of the family: global patterns and their impact on diverging development. Studies in Economic History, Springer, Berlin, pp 149-172

Dennison T, Ogilvie S (2014) Does the European marriage pattern explain economic growth? J Econ History 74(3):651-693

Derouet B (1996) Nuptiality and family reproduction in male-inheritance systems: reflections on the example of the Franch-Comté (17th-18th centuries). Hist Fam 1:139-158

Devance L (1977) Le féminisme pendant la Révolution française. Ann Historiques De La Révolution Française 229:341-376

Devos I (1999) Marriage and economic conditions since 1700: the Belgian case. In: Devos I, Kennedy L (eds) Marriage and rural economy Western Union since 1400 comparative rural history of the North Sea Area. Brepols, Turnhout, pp 101-132

Diebolt C, Perrin F (2013) From stagnation to sustained growth: the role of female empowerment. Am Econ Rev 103(3):545-549

Diebolt C, Perrin F (2017) Understanding demographic transitions population economics. An overview of French historical statistics. Springer International Publishing, Berlin 
Diebolt C, Perrin F (2019) A cliometric model of unified growth. family organization and economic growth in the long run of history. In: Diebolt C, Carmichael S, Dilli S, Rijpma A, Störmer C (eds) Cliometrics of the family: global patterns and their impact on diverging development. Studies in Economic History. Springer, Berlin, pp 7-31

Diebolt C, Menard A-R, Perrin F (2017) Behind the fertility-education nexus: what triggered the French development process? Eur Rev Econ Hist 21:357-392

Didier B (1988) Les femmes et la diffusion des Lumières. Man and Nature / L'homme et la nature 7:23-52

Dilli S (2016) Family systems and the historical roots of global gaps in democracy. Econ History Develop Reg 31(1):82-135

Duhet P-M (1977) Les femmes et la Révolution : 1789-1794. Gallimard/Julliard, Paris

Dupâquier J (1997) La France avant la Transition Démographique, In : Jean-Pierre Bardet et Jacques Dupâquier (dir.), Histoire des populations de l'Europe. 1. Des origines aux prémices de la révolution démographique, Paris, Fayard, 441-462.

Duranton G, Rodriguez-Pose A (2009) Family types and the persistence of regional disparities in Europe. Econ Geogr 85:23-47

Duverger A (1872) De la condition politique et civile des femmes. Marescq, Paris

Eggerickx T (2004) La dynamique démographique et la transition de la fécondité dans le bassin industriel de larégion de Charleroi, de 1831 à 1910, Histoire Quantitative et développement de la Belgique, 1ère série, xixe siècle, t. iii, vol. 1, Les forces de production, Bruxelles, Académie Royale de Belgique

Fauré C (2006) Doléances, déclarations et pétitions, trois formes de la parole publique des femmes sous la Révolution. Annales Historiques De La Révolution Française 344:5-25

Fauve-Chamoux A (1991) Société rurale prérévolutionnaire et démographie différentielle, Historiens et populations, Etienne Hélin, Louvain-la-Neuve, pp 129-146.

Fayolle C (2013) Genre, savoirs et citoyenneté. Les enjeux politiques de l'éducation des filles de 1789 aux années 1820, thèse sous la direction de Michèle Riot-Sarcey, histoire, Université Paris 8

Fayolle C (2014) Former la « femme nouvelle », La Révolution française, 6.

Fénélon F (1687) De l'Éducation des filles de Fénelon, Imprimerie d'Antoine Lambin, Paris

Filmer D, Pritchett LH (2001) Estimating wealth effects without expenditure data - or tears: an application to educational enrollments in states of India. Demography 38(1):115-132

Fleury C (1687) Traité du choix et de la méthode des études, Imprimerie d'Antoine Lambin, Paris

Flinn M (1981) The european demographic system, 1500-1820. Johns Hopkins University Press, Baltimore

Foreman-Peck J (2011) The western european marriage pattern and economic development. Explor Econ Hist 48(2):292-309

Galloway PR, Lee RD, Hammel EA (1998) Urban versus rural: fertility decline in the cities and rural districts of Prussia, 1875 to 1910. Eur J Popul 14:209-264

Galor O, Moav O (2002) Natural selection and the origin of economic growth. Quart J Econ 117:1133-1191

Galor O, Weil DN (2000) Population, technology, and growth: from Malthusian stagnation to the demographic transition and beyond. Am Econ Rev 90:806-828

Galor O, Moav O, Vollrath D (2009) Inequality in landownership, the emergence of human-capital promoting institutions, and the great divergence. Rev Econ Stud 76(1):143-179

Garden M, Le Bras H (1988) La dynamique de la population française, In : Histoire de la population française, vol. 3 : De 1789 à 1914, Jacques Dupâquier, éd., Paris, Presses universitaires de France, pp 117-166

Godineau D (1988) Citoyennes tricoteuses. Les femmes du peuple à Paris pendant la Révolution française. Perrin, Paris

Godineau D (2011) Le genre de la citoyenneté, ou quelle identité politique pour les femmes pendant la Révolution française? Bellavitis, Anna/Edelman, Nicole, Genre, femmes, histoire en Europe. Presses universitaires de Paris Nanterre, Paris, pp 315-339

Godineau D (2015) Les femmes dans la France moderne, XVIe-XVIIIe siècle, Paris, Armand Colin, Collection $\mathrm{U}$

Goodman D (1996) The republic of letters: a cultural history of the french enlightenment. Cornell University Press

Greif A (2006) Family structure, institutions, and growth: the origins and implications of western corporations. Am Econ Rev 96(2):308-312 
Guibert JAH (1786) Le connétable de Bourbon, Paris.

Gutmann MP, Leboutte R (1984) Rethinking protoindustrialization and the family. J Interdiscip History 14(3):587-607

Habermas J (1991) The structural transformation of the public sphere: An inquiry into a category of bourgeois society. MIT Press, Cambridge

Hajnal J (1965) European marriage patterns in perspective. In: Glass DV, Eversley DEC (eds) Population in history: essays in historical demography. Arnold, London, pp 101-143

Hajnal J (1982) Two kinds of preindustrial household formation system. Popul Dev Rev 8(3):449-494

Hajnal J (1983) Two kinds of preindustrial household formation system. In: Wall Richard, Robin Jean, Laslett Peter (eds) Family forms in historic Europe. Cambridge University Press, Cambridge, pp 65-104

Henning M, Enflo K, Andersson F (2011) Trends and cycles in regional economic growth: How spatial differences shaped the Swedish growth experience from 1860-2009. Explor Econ History 48(4):538-555

Henry L, Houdaille J (1978) Célibat et âge au mariage aux XVIIIe et XIXe siècles en France : I. Célibat définitif. Population 33:43-84

Henry L, Houdaille J (1979) Célibat et âge au mariage aux XVIIIe et XIXe siècles en France : II. Age au premier mariage. Population 34:403-442

Jolibert B (2007) La Révolution française et le droit des femmes à l'instruction : Résumé d'une désillusion, IUFM de la Réunion, pp 108-134

Jolliffe I (2002) Principal component analysis, 2nd edn. Springer, New York

Kesztenbaum L, Rosenthal J-L (2017) Sewers' diffusion and the decline of mortality: the case of Paris, 1880-1914. J Urban Econ 98:174-186

Knodel J, Van de Walle E (1979) Lessons from the past: policy implications of historical fertility studies. In: Coale AJ, Watkins SC (eds) The decline of fertility in Europe. Princeton University Press, New Jersey, pp 390-419

Landry A (1934) La révolution démographique : études et essais sur les problèmes de la population, Re-Ed. Sirey, Paris INED, 1982

Le Bozec C (2019) Les femmes et la Révolution : 1770-1830. Passés Composés, Paris

Le Bras H (1996) Histoire et systèmes démographiques. Ann de Démographie Historique 1996:359-372

Le Bras H, Todd E (2013) Le mystère français. Seuil, Paris

Le Bris D (2016) Family characteristics and economic development, Available at SSRN: https://ssrn. com/abstract $=2511173$

Le Bris D, Tallec R (2021) The European marriage pattern and its positive consequences. MontesquieuVolvestre, 1660-1789, MPRA Paper, No. 105324

Le Mée R (1986) Une affaire de « faiseuses d'anges » à la fin du XIXe siècle. Commun Numéro Thématique : Dénatalité : L'antériorité Française 1800-1914(44):137-174

Le Naour J-Y, Valenti C (2003) Histoire de l'avortement (XIXe-XXe siècle). Le Seuil, Paris

Le Roy Ladurie E (1967) Histoire du climat depuis l'An Mil, Paris, Poche Flammarion, 1983

Lee I, Yang J (2009) Common clustering algorithms, In: Brown SD, Tauler R, Walczak B (Eds.), Comprehensive Chemometrics: Chemical and Biochemical Data Analysis, pp 577-618.

Levine D (1977) Family Formation in an Age of Nascent Capitalism. Academic Press, New York

Livi Bacci M (1999) La population dans l'histoire de l'Europe. Seuil, Paris

Malthus TR (1798) An essay on the principle of population, as it affects the future improvement of society, London: J. Johnson

Mason KO (2001) Gender and Family systems in the fertility transition. Popul Dev Rev 27:160-176

Mazeau G, Plumauzille C (2015) Penser avec le genre : Trouble dans la citoyenneté révolutionnaire, La Révolution française, Cahiers de l'Institut d'histoire de la Révolution française

Mendels F (1984) Niveau des salaires et âge au mariage en Flandres, XVIIe-XVIIIe siècles. Ann Econ Soc Civil 5:939-956

Michelet J (1855) Les Femmes de la Révolution, Paris, A. Delahays.

Moheau JB (1778) Recherches et Considérations sur la population de la France, Re-Ed. Eric Vilquin, Paris, INED, 1994

Mokyr J (2009) The enlightened economy: an economic history of Britain, 1700-1850. Yale University Press

Notestein FW (1945) Population - the long view. In: Schultz TW (ed) Food for the world. University of Chicago Press, Chicago, pp 36-57 
Omran AR (1971) The epidemiologic transition. a theory of epidemiology of population change. Mémorial Fund Q 49:509-539

Ourliac P, de Malafosse J (1968) Histoire du Droit Privé. Le droit familiale, Presses Universitaires de France, Paris, Tome III

Perrenoud A (1988) Espacement et arrêt dans le contrôle des naissances, Annales de Démographie Historique, pp 59-78

Perrin F (2013) Gender equality and economic growth in the long run: a cliometric analysis, Université de Strasbourg (France) and Scuola superiore Sant'Anna di studi universitari e di perfezionamento (Pisa, Italy), Ph.D. thesis

Perrin F (2021) Can the historical gender gap index deepen our understanding of economic development? J Dem Econ. https://doi.org/10.1017/dem.2020.34

Perrin F, Benaim M (2019) Regional patterns of economic development: france during the industrialization”. In: Diebolt C, Carmichael S, Dilli S, Rijpma A, Störmer C (eds) Cliometrics of the family: global patterns and their impact on diverging development. Studies in Economic History. Springer, Berlin, pp 197-235

Phillips RG (1979) Le divorce en France à la fin du XVIIIe siècle. In: Annales. Economies, sociétés, civilisations. 34(2):385-398

Roche D (1993) La France des Lumières, Fayard

Rocher G (1973) L'idéologie du changement comme facteur de mutation sociale. In: Rocher G (ed) Le Québec en mutation. Montréal. Hurtubise H.M.H, pp 207-221

Salles A (2019) Birth control in Europe. 19th-21st centuries, Encyclopédie pour une Histoire Nouvelle de l'Europe, hal-02081705

Sharp P, Weisdorf J (2012) French revolution or industrial revolution? A note on the contrasting experiences of England and France up to 1800. Cliometrica 6:79-88

Spolaore E, Wacziarg R (2014) Fertility and modernity, Working paper, Anderson School, UCLA

Squicciarini MP, Voigtländer N (2015) Human capital and industrialization: Evidence from the age of enlightenment. Q J Econ 130(4):1825-1883

Stanton EC (1898) Eighty years and more: reminiscences 1815-1897. T. Fisher Unwin, New York

Szołtysek M, Poniat R, Klüsener S, Gruber S (2019) Family organisation and human capital inequalities in historic Europe: testing the association anew. In: Diebolt C, Carmichael S, Dilli S, Rijpma A, Störmer C (eds) Cliometrics of the family: global patterns and their impact on diverging development. Studies in Economic History. Springer, Berlin, pp 83-119

Tackett T (1986) La Révolution, l'Église, la France, Les Éditions du Cerf, Paris

Therborn G (2004) Between sex and power: family in the world 1900-2000. Routledge, London

Todd E (1983) La Troisième Planète. Seuil, Paris

Todd E (1990) L'invention de l'Europe. Seuil, Paris

Todd E (2011) L'origine des systèmes familiaux, Tome 1, L'Eurasie. Gallimard, Paris

Van de Walle E (1986) La fécondité française au XIXe siècle. Communications 44:35-45

Van Zanden JL, Carmichael S, De Moor T (2019) Capital women: the european marriage pattern, female empowerment and economic development in western europe 1300-1800. Oxford University Press

Vandenbroeke C (1987) Agriculture flamande et démographie (XVe-XIXe siècles), In : Antoinette FauveChamoux (dir.), Évolution Agraire et Croissance Démographique, Liège, pp 325-346

Vivier N (2014) Des populations rurales prolifiques ou malthusiennes ?, Espace, Populations, Sociétés, 1. https://doi.org/10.4000/eps.5666

Voigtländer N, Voth HJ (2006) Why England? Demographic factors, structural change and physical capital accumulation during the industrial revolution. J Econ Growth 11(4):319-361

Voigtländer N, Voth HJ (2013) How the west 'Invented' fertility restriction. Am Econ Rev 103(6):2227-2264

Vovelle M (1977) Le tournant des mentalités en France 1750-1789: La sensibilité pré-révolutionnaire. Social History, pp 605-629

Weir DR (1984) Life under pressure: France and England, 1670-1870. J Econ History 44:27-47

Wetherell C (2001) Another look at Coale's indices of fertility, If and Ig. Soc Sci Hist 25(4):589-608

Wrigley EA, Schofield R (1981) The Population history of England, 1541-1871: a reconstruction. Cambridge University Press, New York

Publisher's Note Springer Nature remains neutral with regard to jurisdictional claims in published maps and institutional affiliations. 